




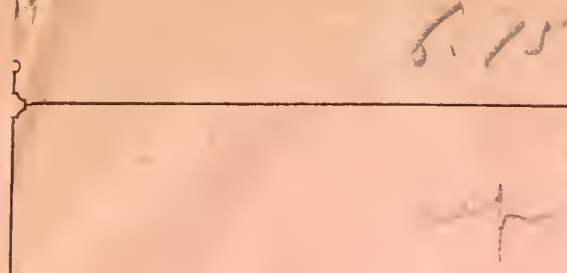

\section{NÅGRA BLAD}

\section{UR NATURENS BOK.}

O. M. Itentar.

I.

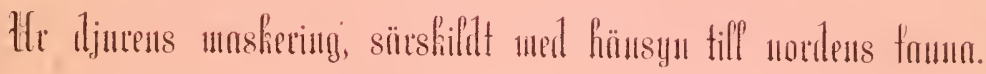

\section{HELSINGFORS,}

J. Simelii arfvingars tryckeri, $\quad \varepsilon_{79}$.

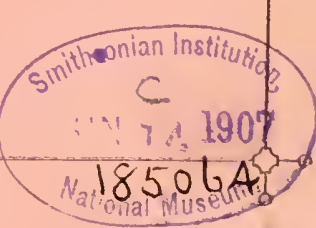





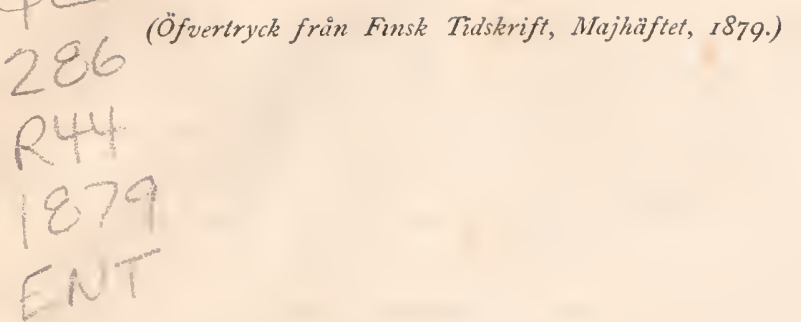

\section{Några blad ur naturens bok.}

I.

Ur djurens maskering, särskildt med hänsyn till nordens fauna.

1.

I mer än ett afseende skiljer sig den moderna naturalhistorien frin flydda tiders. Barnskorna äro uttrampade; den blotta iakttagelsen är henne icke mera nog; hon har börjat att sjelfständigt tänka öfver tingen. Och det är icke mera en lössläppt fantasis bilder, som leka för henne, - hon går ej mera i en spekulatir filosofis skola; hon har blifrit vis af skadan och med den enkla deduktions- och induktions-metod, enligt hvilken hvarje sund tanke kan operera, har hon ur de henne mötande företeelserna uppsökt lagarna i naturen och kring dem grupperat de sürskilda fakta. Så är hon icke mera blott ett tomt register öfver sådana, öfver föremålen i naturen och särskilda observationer angáende dessa, men hon är en rerklig historia öfver dem, deras inbördes sammanhang, deras orsak och verkan, deras lif i dess egentligaste mening, hou har ändteligen höjt sig till samma rang som t. ex. kemin och fysiken, hon är en retenskap. Och att hon jämförelsevis sent nått denna ståndpunkt, beror deraf att hon, vetenskapen om de lefvaude, organiska varelserna och om lagarne för deras lifs fenomen, redan i följd af sitt imnehåll måste ställas högst af alla naturvetenskaper och häri innebär vilkoren för sin sena utveckling. Hon har blott följt den lag, som gäller för de föremål, hon sjelf behandlar, att det högsta tillika är det sista i kedjan.

Det är några blad ur denna retenskap, med hrilka vi i det följande önska göra våra läsure bekanta. Iri vilja välja nå- 
gra sådana, som synas oss hafva allmännare intresse; och om de äfven i månget fall lata oss betrakta naturen med andra ögon än förr och tvinga oss att offra mången poetisk tanke, som hittills fylt vâr själ vid naturens åskådning, så tro ri dock förvisst att det mindre offras för det större och att dessa offer på sanningens altare rikligen belönas genom de stora vyer, hvilka dervid öppnas för oss $\mathrm{i}$ naturens innersta rerkstad. Naturbarnet, som skådar upp till den klara natthimlen med dess tusen ljus, erfar en obestämd känsla af det oändeliga och en fridfull andakt faller öfver dess sinne; men hrilken långt djupare poesi förmår icke astronomen frånvinua himlahvalfvet, väl ej lika omedelbar, men $\mathrm{i}$ stället af sâ oändeligt mycket högre art? Han tror vail icke mera att Skaparen i sin godhet gjort miljoner strålande verldar blott till ïgnafägnad för en rarelse på en bland de minsta af dem; men han stâr häpen af beundran inför de lagar, som sammanhâlla denna oändliga verlds-mekanism, under det känslan af detta oändeliga icke mera verkar på honom såsom en blott obestämd stämning; med sin ande kan han omfatta hela denna komplex af miljoner verldar och miljonertal mil, och, om någon, njuter han i känslan häraf. Så liten inför alltet han ¿in känner sig, si̊ höjes han dock derjämte öfrer detsamma. Detta är vetenskapsmannens himlastege, på hvilken han stiger till möte med Gud.

Och så är det öfrer allt i naturen för naturforskaren, der han går fram. Vi få lemua vâr småaktiga och fâfänga egenkärlek, som tror att allt blifrit skapadt för oss; vi fä lära oss att fåglarnes sånger icke äro till för att fägna vårt öra, lika litet som ängens fagra blomster vårt öga; vi fa till sist nöja oss att med ieke allt för stort börds högmod skåda ned pâ de varelser, hvilka jämte oss och så räl som vi hafva rätt till denna jord. Men då ri så nödgas ödmjuka oss för sauningens skull, fyller hon ess $i$ stället med en ända in $i$ vâr andes djup gripande känsla af beundran, som icke är blott en ögonblickets stämning; framkallad pâ de yttre simnenas väg, men som på tankens böljor flutit in $\mathrm{i}$ vårt innersta, för att der bestå och ständigt ânyo lâta oss erfura sin tjusning. Detta är retenskapens poesi, der hrarje ord är sanning, och der till hrarje bokstaf kan 
förknippas en hel serie af tankar och föreställningar. En from man har sagt att öfver nästan hvarje ord i bibeln en predikan kunde skrifras. Sâ ock med naturens bok, ty också hon innehâller - Guds ord.

Nå väl, vi vilja taga en text, som helt risst skall synas mângen i hög grad obetydlig. $V i$ vilja till en början tala om djurens färg, för att sedan leda oss till några anmärkningar om deras form. Medgifrom att de flesta af oss icke närmare tänkt öfrer detta ämue; och jag är dock viss pâ att, innan vi lemna det, vi skola göra det med en ny verld af föreställningar och bilder inom oss.

Det är med naturalhistorien såsom med de gamle egyptiers hieroglyfer. Dess teckenskrift är icke lätt att tyda; först genom talrika kombinationer kumna ri leda oss till de enskilda hieroglyfernas mening. Och ett bevis på att vi fattat dem rütt se vi deri att vi, sedan de en gång blifvit tydda, kumna läsa oupphörligt mer och mer, kunna ur de nya sammanställningar af dem, som möta oss, hemta allt fort nya meningar. I sjelfra verket lemnas det bästa beviset på en teoris rigtighet deri, att hon i sig kan upptaga och förklarn allt flere nya fakta, som upptäckas.

Vi vilja derför nu först lära känna de enskilda hieroglyfer, hvilka bilda vår text; lâtom oss sedan lyssna till den tolkning, forskarene lemnat af de samma.

På samma sätt som de forntida ristuingarne i hällarne länge och väl betraktades såsom märkliga kuriosa, utan att man ens kom på den tanken att de i sig kunde innefatta någon mening, tills man omsider fann att dessa streck dock hade en viss regelmässighet, att de àterfunmos i bestämda sammanställningar, o. s. v., ja tills man slutligen i clem förvânad såg ett helt språk med en skatt af ovärderlig kunskap för historieforskaren; sá har det äfven varit med naturalhistoriens hieroglyfer. Ända till senaste tid hafra nånga, äfven framstâende forskare gâtt förbi dessa streck och linier i naturvetenskapen utan att $\mathrm{i}$ dem se något vidare. Men äfven deras förlossare och lifgifvare skulle komma, likasom ockșå stenarues bundna språk räcktes till lif g'enom den lärdes trollstaf. 
Då det gält stora och epokgörande upptäckter har ofta den anglosachsiska racen gått i första ledet. Så äfven här. Det befruktande snillet ensamt är det, som i den döda materien kan inblåsa den lefrande ande, hvarpå denna väntat. Och ett sådant snille fann hou i Charles Darwin.

Lärde Limné oss att stafva, har Darwin och hans skola lärt oss att läsa. Låtom oss följa en af hans förnämsta samtida, Alfred Russel Wallace, då vi nu öfvergå till vårt ämne. En bättre ledsagare vid studiet af de typer, vi komma att betrakta, kunna vi icke önska oss.

Ar 1867 offentliggjorde Wallace i den ansedda engelska tidskriften : Westminster Review en uppsats, hvilken han kallade Nimicry and other Protective Resemblances among Animals«, och hvilken jümte flere andra af icke mindre intresse han sannmanförde âr 1870 i ett särskildt arbete: Contributions to the theory of Natural Selection«. Det är med detta arbete i hand vi vilja begynna vâr vandring $i$ naturens stora museum; och vi skola dervid hufrudsakligen fästa oss vid de typer, som ligga oss närmast, vid de nordiska formerna, vid det som rår egen fauna har att framte. Nödgas vi än derigenom förbigå Here af de mest intressanta fallen, så âterstår oss dock mycket af betydenhet, och måhända skola vi dervid kumna framleta ett och annat, som ännu icke blifrit stäldt i sammanhang med det ämne, som nu sysselsätter oss.

En af de rigtigaste lagar inom den organiska naturen, pia hvilka Darwin gjort oss uppmärksamma, är utilitets-eller nyttighets-principen, hvarmed han menar att intet särskildt organ, ingen karakteristisk form eller teckning, ingen egendonlig instinkt eller vana, intet förhållande arter eller artgrupper emellan kan existera utan att detsamma antingen är eller någon gång har varit nyttigt för de individer eller racer, som deraf utmärkas. Och i sanning, uppställandet af denna princip är likasom en lykta, som belyser för oss en hel mängd småsaker, hvilka annars utan trifvel undginge oss, men nu den ena efter den andra träda $i$ ljuset och låter oss ana att hvarje karakter, huru minutiös den än må vara, huru betydelselös den än må synas, dock eger ett heständt ändamål, en egen mening. 
En stor mängd djur hafva ett alldeles nödvändigt behof att dölja sig, att göra sig osynliga för sina fiender eller ock för att derigenom lättare kunna nalkas sitt rof. I hvartdera fallet står detta behof i närmaste samband med och utgör ett vilkor för djurets existens. Detta behof är än större för de djur, hvilka annars icke ega något försvarsmedel. Och det bästa skydd, som kan lemnas, består deri att djuret så mycket till sin färg liknar omgifningen, att det derigenom mindre lätt faller i ögonen. En allmän likhet till färgen med lokaliteten, hrarest djuret vistas, är derför det första, som utilitets-principen kan sägas fordra för annars icke skyddade djur.

Vi vilja med blicken på vâr fauna undersöka i hvad mån denna fordran är uppfyld. Till en början erimra vi oss de tvâ stora grupper af djur, vi kumna âtskilja med afseende å den tid, de äro i rörelse. Och härvid rinner oss genast i hågen att den mörka färgen är en allmän regel för alla nattdjur. Möss, râttor, mullvadar, nattlappar ega de minst $\mathrm{i}$ ögonen stickande färger och blifva nästan osynliga på en tid af dygnet, då en ljus färg onekligen lätt skulle röja dem. Ugglor och getmjölkare ega en mörkt spräcklig fjäderbeklädnad, som gör dem osynliga om natten, på samma gång densamma genom sin likhet med trädens bark och lafbeklädnad utgör ett godt skydd för dem om dagen. Och det är kändt att nattfjärilarne (Noctuce) nästan samteligen äro mörka, under det dagfjärilarne briljera med den mest lysande färgprakt, likasom äfven att de flesta natt-skalbaggar utmärkas af svarta, matta färger. Äfrensâ hafva de arter, som föra ett underjordiskt lif eller lefva i mörker (Blaps) och grottor, mörka eller bleka färger. Att bland dem t. ex. söka en metallisk art skall väl städse vara fåfängt.

Men frannse vi den tid, på hvilken djuren lefva, skola vi äfven efter lokaliteten öfverhufvud anträffa en i ögonen fallande färgadaption. Så anför Wallace att okendjur i allmänhet hafva en påtaglig sandfärg och Rev. Tristam har berättat från norra Afrika att derstädes utan undantag öfre fjäderdrägten hos harje fägel, vare sig lärka, sångare eller sandhöna, och äfven pelsen hos alla smärre däggdjur, skinnet hos alla snokar och ödlor är enformigt isabell- eller sandfärgadt. 
Nordens fauna erbjuder en analogi härmed i de snöfärgade djuren. Isbjörnen är den enda björn, som är hvit, och den lefver städse ibland snö och is. Jagt-falken (Falco gyrfalco), fjellugglan (Nycter nivea) och snösparfren (Plectrophanes nivalis) äro alla hvitfärgade innevånare $\mathrm{i}$ den arktiska zonen och helt risst tjenar denna deras färg till att dölja dem. En del djur âter blifva blott till vintern hvita; sâlunda förändrar den nordiska haren (Lepus timidus) sin färg, under det deremot mellersta Europas hare (L. europceus) hela året om eger samma efter den grâbruna mon lämpade drägt; den amerikanska polarharen àter, som nästan städse bebor evigt snöbetäckta regioner är deremot hvit under hvarje årstid. Bland fâglarne hafva vi i ripan ett utmärkt exempel på protektiv likhet. Enhvar ret att denna fagel under vintern blir hrit, under det hon deremot om sommaren eger en färgdrägt, hvilken så exakt harmonierar med de laftäckta stenarne, att man »kan gå genom en hel flock ripor utan att se en enda af dem ". Den skotska ripan (Lagopus scotica), hvilken vistas bland ljungen på de skotska fjällen, der snö blott sällan faller, byter derför icke heller om färg, utan har under hela sitt lif samma rödbruna spräckliga drägt, som så ypperligt döljer henne bland ljungen. Jag erinrar mig ännu lifligt frân mina vandringar i de skotska högländerna, huru ofta jag var hardt när att trampa på den ena moripan efter den andra, då de icke förr flögo upp än foten var öfver deras nacke. I ofvan anförda fall är det alldeles klart att den hvita färgen rore högst ofördelaktig om sommaren för både haren och ripan, under det âter deras sommarkostym, som under denna årstid är så lämplig för dem, under vintern deremot läte dem ganska lätt bli upptäckta på snöfälten; här utgör den protektira likheten i färg för dem ett särdeles godt skydd mot fiender. Men äfren arktiska rofdjur förändra på samma sätt sin drägt efter årstiderna. Sålunda blifva fjellrackan (Canis lagopus) och hermelinen samt lilla vesslan (AIustela erminea och nivalis) hvita till vintern. Måhända kunna de härigenom underlättas att nâ sitt byte och blifva derigenom mindre utsatta för att hungra ihjäl.

Men det är icke blett ibland de högre djuren, som en sådan imitation efter den för ârstiden utmärkande färgen $\mathrm{i}$ natu- 
ren eger rum. Rev. Greene, en bekant britisk entomolog, har fästat uppmärksamheten vid harmonin emellan naturens förherskande färger under höst och vinter och färgerna hos de under dessa tider flygande britiska fjärilarne. Om hösten, då brunt och gult äro förherskande, visar det sig äfven att af femtiotvå då flygande fjärilarter icke färre än fyratiotrå visa motsvarande färger, t. ex. Orgyia antiqua, O. gonostigma, slägtena Xanthia, Glea och Ennomos. Om vintern, då hvitt och silfverfärg utmärker naturen, hafva vi häremot korresponderande arter inom slägtet Chimatobia samt i àtskilliga arter af Hibernia. En annan britisk naturforskare, den skotske entomologen och botanisten Buchanan White har anmärkt att bland skinnbaggarne finnes ett slägte, Miris, hvilkets arter visa den egenheten att de tidigare under sommaren, medan gräset, bland hvilket de lefva, ännu är friskt, äro gröna, hraremot de emot hösten, då gräs- och sädes-slag gulnat, uppträda $\mathrm{i}$ en ochragul form. I det förra fallet imitera de sålunda chlorophyllen, i det senare phylloxanthinen hos vexterna. Då dessa höstformer öfvervintra för att âter framkomma om våren, men då äro gröna, synes det som om här förelåge en egendomlig, under vinterdvalan framkallad färgförändring, med hrilkens rätta art entomologerna dock ännu icke äro på det klara $^{1}$ ).

Emellertid hafva vi således redan funnit att en allmän öfverensstämmelse förefinnes emellan de på olika trakter, olika årstider eller olika tider af dygnet herskande färger och färgen hos de für dem egna djur-arterna. $\mathrm{Vi}$ skola $\mathrm{i}$ det följande få se en ännu mera detaljerad tillämpning af samma grundlag. Härvid torde det måhända vara lämpligast att följa djurserien klass för klass för att teckna oss till minnes de exempel på protektiv färg-likhet, som möta oss.

Hrad beträffar vâr jämförelseris fattiga däggdjurs fauna hafva vi redan anfört allt nämnvärdt. Bland făglarne âterstâ ännu några fall att omtala. I sitt arbete »Reign of Law har

1) Se närmare härom i min afhandling: „Till kännedomen om mimiska hemiptera och deras lefnadshistorias (Öfvers. af Finska Vetenskaps-Societetens Förhandlingar, XXI, p. 153). 
hertigen af Argyll påpekat den beundransvärda adaption, som morkullan företer. De omvexlande bruna, gula och askgrå-färgerna, som förekomma bland fallna löf, äro alla representerade i hennes fjäderbeklädnad, så att hon är nästan omöjlig att upptäcka der hon står på marken under träden. Också hos snäpporna är färgen modifierad så att den står i full harmoni med de förherskande formerna och kulörerna i sumpmarkernas vegetation. Mr Lester har anmärkt att skogsdufvan der hon sitter på grenarne af sitt favoritträd, furan, blir mycket svårt synlig, hvaremot dess bla- och purpur-glänsande färg mycket hastigare förråder henne ibland löfträdens ljusare grönska.

Bland reptilier och batrachier, som tillhöra skandinaviens orh vår fauna, ega vi äfven exempel på färgimitation. Huggormen och ormslån hafva båda en färg efter sand och hed och helt risst är det denna omständighet, som förorsakar att man så ofta först i sista ögonblicket blir rarse den förra, der han ligger hopringlad på rägen eller vid stenröset. Ödlorna, som springa omkring bland riset på våra backar, äro brun- eller grå-aktiga, som detta, och grodorna, hrilka hoppa på mossarne, efterlikna dem i den bleka färgtonen. Deremot är löfgrodan, som förekommer i Skånes bokskogar och lefver uppe bland trädens blad, lifligt grön.

Bland fiskarna känna vi alla flundran, om hvilken man redan länge vetat att hon eger förmåga att förändra färgtonen hos den färgade sidan, som hon ränder uppåt, allt efter den färg, som är rådande på det botten, hvarpå hon ligger. Sålunda blir hon ljusare på sandbotten, mörkare på dybotten; och denna förändring undergår en och samma individ, om han flyttas till olikartade lokaler. För öfrigt finna vi att äfven de aborrar, hvilka lefva hos oss i de små träsk, som hafva så kalladt svart vatten (» Mustajärvi «, 》Svart-träsk ", o. s. r., af hrilka vi hafva talrika i vårt land), alltid äro mycket mörkare, än de, som träffas i större träsk med ljusare botten eller i östersjön och dess vikar. Och slutligen gäller det såsom en allmän regel att sádana arter, som hålla sig nästan uteslutande till bottnet, såsom âlen, malen (Silurus gianis) och paddfisken (Lophius piscatorius) äro mörka och utan den silfverglans, som mestadels ut- 
märker fjälleu hos de andra. Vi gå måhända icke för långt, då vi äfven i sjelfva denna silfver- eller perlemor-glans, som är sâ karakteristisk för fisk-klassen öfrer hufvud, se en imitation efter vattnet, hvilken gör fiskarne mången gång mindre lätt åtkomliga för andra roffiskar, än de annars vore.

Med hänsyn till molluskerna vilja vi endast nämna att de ofta utmärkas af en mörk färg, som lämpar sig väl för deras lefnadssätt.

Men det är hufrudsakligen inom insekternas så formrika och så mångskiftande klass, som de flesta och tillika de märkvärdigaste exemplen på färgimitation förekomma. Här är det så allmänt att arternas färg stâr i samband med den omgifvande lokalitetens, att man i sanning jåkar i villrådighet vid val af exempel. De flesta af de på marken lefvande äro mörka och matta; brunt, grått och svart äro här förherskande. Vi vilja kasta en blick på rätvingarnes ordning och vi skola frapperas af den efter olika vistelse orter rådande färgadaptionen. Den uppe i buskarues eller löfträdens kronor lefvande stora gröna vårtbitaren (Locusta vividissima) är helt och hållet blad-grön; de på ängarne lefvande arterna (Locusta verrucivora, Decticus, Gomphocerus, med flere) äro gröna med inblandning af brunt, gult eller rödt; den på torra backar hoppande trumgräshoppan (Oedipoda stridula) är brun eller brungrå; den på klippor och bergsklackar lefvande Pezotettix pedestris är grå, den bland de torra löfven i våra skogar springande kakerlacken (Blatta lapponica och livida) brungul samt den under stenar, mellan barkspringor m. m. om dagen dolda, egentligen blott nattetid sig rörande trästjerten (Forficula auricularia och minor) brun eller svartbrun; slutligen är hus-syrsan (Acheta domestica), som lefver i våra spislars och skorstenspipors mörker, svartaktig. Och liknande exempel erbjuda oss alla ordningar.

Men också arter af samma slägte förhålla sig pâ ett liknande sätt. Så hafva vi hos oss tre arter af de så kallade tigerbaggarne (Cicindela), af hvilka den allmännaste, C. campestris, om våren flyger och springer efter rof på gräsiga skogsbryn och särdeles bland den med ung grönska då prunkande ljungen; han är derför grön, hraremot den på ännu torrare ställen lefvande 
C. sylvatica är mörkbrun och den uteslutande på sandig hafskust förekommande $C$. maritima har en blekt bronzerad gul färg, som derstädes gör henne nästan alldeles osynlig ${ }^{1}$ ). En ypperlig imitation efter färgen förekommer också hos en annan rofskalbagge, som stâr nära till detta slägte, Nebria livida, hvilken äfvenledes uteslutande lefver på sandiga sjöstränder.

Men färgadaptionen inskränker sig icke blott till en sådan likhet i allmänna drag. Särdeles lärorik är fjärilarnes ordning. Vi veta att dagfjärilarne under hvilan hafva för vana att slå upp sina vingar i upprät ställning, under det deremot nattfjärilarne lägga dem takformigt öfver hvarandra, så att det öfre vingparet täcker det undre. Båda äro de i lika hög grad $\mathrm{i}$ behof af skydd under hvilan. Och vi finna i sjelfva verket att dagfjärilarue hafva lysande färger på öfre ytan af alla fyra viugarne, medan deremot dessas undre sida oftast är mörk och matt; nattfjärilarne ater hafva vanligen, då de ega någon mera $\mathrm{i}$ ögoneu stickande färg, denna på de undre vingarne, under det de öfre äro mörka och, sâsom vi skola se längre fram, ofta utmärkta af imitativa kulörer, hvilleet senare för öfrigt äfven ofta är fallet med den undre sidan af dagfjärilarnes vingar. Detta är just hrad vi harle bordt vänta. Den gramna rödbårdade admiralen ( $V_{r-}$ nessa atalanta), den rödbruna nässelfjärilen ( $V$. urticre) och flere andra hlifra med ens nästan osynliga, då de slå ned antingen på vägens mull eller på plank och husväggar. Den lilla Thecta mbi, som on våren med sina bruna vingar Haddrar öfver lingonriset, försvinner för vår i̊syn, så snart hon sätter sig ned på detta och slår upp den gröna undersidan af sina vingar. Blåvingen (Cupido argus), som flyger öfver de ljungberuxna bergen i våra skogar, är svår att upptäcka, så snart han satt sig ned pâ stenen och slagit ihop sina undertill grå vingar. Likaså den metalliska, glänsande guldvingen (Polyomnatus), då han sitter pă sanden och gömmer sitt guld innanför de grå- eller röd-

1) Wallace anfür l. c. p. 57 ïnnu âtskilliga i hög grad märkliga färgadaptioner hos utländska Cicindela-arter. I min redan eiterade uppsats (Öfvers. af Vet.-Soc. Förh., XXI, pp. 144-148) hav jag frỉn ordningen Hemiptera antecknat flere exempel på färgimitation efter olika lokaler hos särskilda arter af några större genera, som förekomma hos oss. 
gula, prickiga baksidorna af vingarne, de der nu äro de enda, som han visar och hvilkas färg hopsmälter med omgifningens. Deu egendomliga perlemorteckningen på undre sidan af perlemor-fjärilarnes (Argymnis) vingar torde, äfven den, vara imitativ. Dessa skiftande fläckar likua glanseu hos de likasom under olika vinklàr slipade små-ytorna på berg och stenar. Anmärkningsvärd är mr IVoods, af Wallace anförda iakttagelse angâende Anthocharis cardamines, denna hvita fjäril med de hos hanen orangeröda vingspetsarue och de på undre sidan så märkvärdigt tecknade bakvingarne med gröna likasom grenigt ådrade figurer. Hau har nemligen funnit att den mot aftonen ofta brukar slâ sig ned på de gröna och hvita blomhnfrundena af Anthriscus sylvestris och att denna vingarnes teckning då sammanflyter med dessa. Tcke mindre beaktansvärd är teckningen på undre sidan af några öfver våra bergklintar flygande arter, såsom Satyrus semele. Det är nästan rakt omöjligt att upptäcka demua art, så snart den satt sig ned på den lafklädda klippan. Jag har otaliga gånger förlorat den alldeles ur sigte, till dess att den flugit upp nästan vid mina fötter och åter visat sina rödgula vingar. Så ända in i de minsta detaljer liknar färgfördelningen på de undre vingarnes baksida färgen hos de tumna lafvarne, hvilka såsom en skorpa smyga sig öfver stenen.

Erån detta fall bland dagfjärilarne ledas vi till likuande hos nattfjürilarne, hvilka om dagen sitta gömda på trädstammar och grenar, i steurösen och dylikt. Här möta oss talrika exempel på färgimitation efter lafvarne och Wallace har i detta afseende ${ }^{1}$ ) särskildt omnämnt Agriopis apritina och Acronycta psi, hvilka båda förekomma äfven hos oss. Jag har bland de till vår fauna hörande arterma ytterligare anteckuat slägtet $X y$ Tina, Agrotis corticen, A. simutans, Aplecta occulta, hvilkas namn tyda på den protektiva färg, de ega; vidare Acronycto aceris, Agrotis precox, Polia chi, Hadena mea och polyodon, HyIroecia nictitans, Xanthia togata, Teotiopteryx Tibatrix, Epioma vespertaria, Amphidasis betularia, flere Boarmia-arter, Thamnonoma vavaria, med flere ${ }^{2}$ ). Icke blott färgen öfver hufrud,

1) 1. c. p. 62 .

2) Jämförelsevis fă fjärilar imitera bladens gröna färg; sådana äro t. ex. 
men teckningarne äuda in i minsta detalj, de zigzagformiga mörka linierna, de njurformiga fläckarne, hvilka efterhärma sporplättarne, allt imiterar till en förvillande grad de lafvar, på hvilka dessa arter slå sig ned för att hvila under dagen, oftast icke skyddade af annat än demna färglikhet. Det behöfver väl ej påpekas att, under det en sådan imitativ färg hos dagfjärilarne förekommer på undre sidan af bakvingarne, den hos nattfjärilarne, till följd af det olikartade sätt, hvarpå de hoplägga sina vingar, igenfinnes på framvingarnes öfre sida ${ }^{1}$ ).

Också bland skalbaggarne förekommer en dylik färgadajtion efter trädens bark och de på denua vexande lafvarne. Det är helt naturligt att den företrädesvis skall stå att anträflas hos arter, hvilkas lefnadssätt stâr i något fürhållande till träden. Och i sjelfva rerket möter den oss hufvudsakligen blaud timmermännens (Longicomernas) familj, hvilkeus representanter såsom larver lefva $\mathrm{i}$ veden. Den förekommer här i de mångfaldigaste variationer, ifrån strödda gula hårfläckar på svart skroflig yta (såsom hos Lamia sutor och sartor) till gula eller hvita teckningar på svart botten (Saperda scalaris) eller svarta sporhuslika fläckar på gult (S. Seydlii) eller fina svarta tättstående prickar på gult eller grått botten ( $S$. charcharias) samt slutligen innu mera komplicerade teckningar (S. populnea, Rhagium, Acanthoderes varius, Liopus punctulatus, m. fl.). Och enhvar, som observerat dessa djur i naturen, der de krypa upp för trädstammarne, skall nödgas medgifva att denna deras färg bidrager att dölja dem för samlarens och då äfren för insektätaude făglars ögon.

En i hög grad frappant imitation efter lafvarne förekommer vidare hos ett skinnbaggs-slägte, Phytocoris, hvars arter sitta på trädens stammar, för att, enligt Kaltenbachs uppgift ${ }^{2}$ ), lura

Earias chlorana, Hylophila prasinana, Geometra papilionaria, Phorodesma smaragdula. Det vissnade bladet efterhärmas ypperligt af Gastropacha qvercus och Platypteryx falcatoria.

$\left.{ }^{1}\right)$ Flere småfjürilar, särdeles af slägtet Bryophila, äro så lika de stenar och vallar, på hvilka de sitta, att de äro nästan omöjliga att upptäcka, dî de hâlla sig orörliga.

$\left.{ }^{2}\right)$ Die Pflanzenfeinàe, pag. 562; min uppsats ১Bidrag till kännedom at mimiska Hemiptera, etc. «, pag. 153. 
på derstädes krypande små bladlöss och larver; i detta fall synes sålunda färgadaptionen tjena ett dubbelt ändamål, att nemligen göra insekten osynlig för fiender och lättare lăta honom obemärkt smyga sig öfver sitt rof.

Slutligen vilja vi anmärka att äfven âtskilliga spindlar imitera lafvarnes färg.

Detta slag af färghärmning är sålunda ganska allmänt representerad inom djurriket. $\mathrm{Vi}$ hänvisa till hvad redan tidigare blifvit yttradt med hänsyn till vissa fagglar.

Men färg-imitationen hos insekterna går ännu längre i detalj och förbinder sig då ofta med en viss grad af efterlikning äfven till formen.

Minst märkvärdiga äro ingalunda de länge kända fallen, då hela qvistar blifva efterhärmade. Bland fullbildade insekter representerar fjärilen Pygaera bucephala ett sådant. Demna fjäril, hvilken med sin mattgrå färg och de med brunt afsneddade äudarne på de hoplagda vingarne om dagarne sitter orörlig på undre sidan af trïdens grenar, liknar till den mest förvillande grad den afbrutna ändan af en trädqrist. Men dylika fall förekomma i synnerhet hos en del larver af mätarefjärilar (Geometre), hvilka hafra en lång trind kropp med tre par fötter vid främre ändan, som slutar i ett trärhugget hufrud, samt vid yttersta bakspetsen åter par fötter. Dâ de oroas pläga de, fästade vid trädgrenar endast med dessa senare, sträcka ut kroppen i vinkel emot grenen och hålla den sålunda fullkomligt styf, stundom Here timmar, med hufvud och framben orörligt ntsträckta i räit linie. En af de största och anmärkningsrärdaste är hos oss larven till Geometra betularia, hvilken lefver pa björk, m. m. och hvilken på sin bruna kropp dessutom har små ljusare vårtor, som ypperligt imitera de små korkpapillerua på qvistarne. Ej mindre märkvärdig är larven af Rumia cratregata. Det är nästan omöjligt att hos dessa ana till att man har framför sig en lefvande varelse; si̊ mästerligt genomförd är likheten med trädqvisten ${ }^{1}$ ). Mr Audrew Murray anmärker äfven, enligt

1) Vidare om imitation efter quistarnes färg, se min of van citerade afhandling, pag. 151. 
Wallace ${ }^{1}$ ), huru nära larven af lilla påfăgelögat (Saturnia pavonia minor), hvilken äfven är funnen hos oss, harmonierar till sin grundfürg med de unga skotten af ljungen, af hvilka hon lefver, medan åter de röda fläckarne, med hvilka hon är prydd, motsvara blommorna och blomknopparne hos samma vext. Klart är äfven att larven lika väl som den utbildade insekten behöfver skyddas; och antecknas bör härrid att sâdana imitatoriska larver emellertid förekomma endast bland arter, hvilka under detta utvecklingsstadium lefva på öppna ställen, såsom fallet är inom fjärilarues och vextsteklarnes grupper. De larver deremot, som lefva i träd, i jorden, såsom parasiter eller inneslutna i hylsor och dylikt, nemligen skalbaggarnes, de öfriga steklarnes, flugornas larver visa aldrig någon efterhärmning. Hos vatteninsekternas larver, såsom larverna inom ordningen Neuroptera och Pseudo-orthoptera, är färg-imitationen äfven sällsynt; enligt uppgift af d:r Palmén skola dock larverna af vissa Ephemerider till deu grad efterhärma färgen på stenarnes yta, att de blott med svårighet observeras, då de hâlla sig stilla. Men hos de af vexter och särdeles af vexternas blad lefvande går den protektiva likheten genom alla grader ända från den gröua färgen ensam till en sådan fullkomning såsom hos vissa Geometre. Jag kan ej underláta att här ytterligare anföra den gröna, på trären svart streckade larven af Papitio machaon, hrilken senaste sommar frapperade mig genom den stora likhet, denna teckning framkallade med de fårade grenarne hos Angelica, på livilka den lefde.

Från trädens grenar ledes tanken lätt till knoppfjällen, blommorna och frukterna. Hos oss förekommer om våren en liten gul eller brungul skalbagge, Orchestes scutellaris, som sitter på trädqristarne af ek och al och i hög grad liknar de lätt affallande, lika färgade knoppfjällen på dessa. Imitationen efter blommor är sällsynt; dock hafva vi åtminstone ett sådant fall hos oss. Ingen, som en längre tid samlat insekter, och dervid besijkt ljunghedarne $\mathrm{i}$ södra delen af vårt land, har väl undgătt att ofta $i$ sin håf bland vissnade fjolgamla ljungblommor finna

1) 1. c. pag. 63 . 
en hoppande insekt, Ulopa reticulata, som erbjuder en slående likhet med en dylik blomma; och har han icke iakttagit denna insekt, så är just denna dess likhet orsaken dertill. Tnsekter, som likna frön, finnas temligen talrikt; Wallace anför ${ }^{1}$ ) efter Kirby och Spence en liten skalbagge, Ontophitus sulcutus, som liknar fröen af en parasollvext. Flere arter inom Anisotomidernas ${ }^{2}$ ) familj ega förmågan att genom imböjandet af hufvud och mellankropp emot bakkroppen och täckvingarne rulla ihop sig till ett litet klot och då de sålunda ligga orörliga likna de ganska myeket atskilliga vexters frön, hvartill derjämte deras glänsande svarta färg bidrager (Cyphoceble, Agathidium). Äfren en del Oniscider (t. ex. slägtet Armaditlo) och tusenfötter (Glomeris) ega en dylik fürmåga att rulla ihop sig och i denna ställning länge och väl förblifva orörliga, hvarigenom djuren få en viss likhet med runda frökapslar eller dylikt.

Wallace omtalar ${ }^{3}$ ) en liten vifvel, utan att nämna dess namn, hvilken rore mycket efterjagad af de rofgiriga Harpalusarterna, men som till sin färgi i hög grad liknar den leriga gyttjan, och hvilken art förekommer särskildt talrik i lergropar. Härvid lemnar han oss ett rikt fält för gissningar, ty redan inom vår fauna finnas flere arter, på hvilka denna beskrifning slår in. Tidigt om våren, sedan snön smultit bort, finner man under stenar på gyttjig grund på sina ställen särdeles talrik en liten vifvel (Trachyphloens), hvilken är särdeles lik små torra gyttjekorn; senare på sommaren kan man från Equisetum på gyttjiga ställen insamla en större art, Erirhimus Equiseti, hvilken, likasom flere mindre på liknande lokaler lefvande arter af samma slägte samt äfven den närstående Tanysphyrus Lemnce, varierar i srart och grått, den senare teckningen så lik torkad gyttja, att man vore frestad att skrapa bort densamma. Skulpturen på täckvingarne underhjelper här yttermera likheten ${ }^{4}$ ).

1) 1. c. pag. 58 .

2) Likaså vissa Palpicornes.

3) 1. c. pag. 58 .

4) Här är platsen att i förbigående beröra en liten skalbagge, Georyssus pygmaus, som förekommer under stenar vid vi̊ra stränder och hvilken vandrar omkring i slammet nüstan alltid betäckt mel en gyttjemassa, som 
Slutligen må ännu ett fall af imitation omtalas, hvilket ingalunda är det minst märkvärdiga. Mr Sidgwick har ${ }^{1}$ ) fästat uppmärksamheten vid några småfjärilar, hvilka, der de sitta på trädens blad, fullkomligt likna på dessa nedfalleu fågelträck. »Jag har sjelf mera än en gång«, säger han, »misstagit Citix compressa, en liten hvit och grå fjäril, för ett stycke făgelträck, som droppat ned på ett löf, och vice versa träcket för fjäriln «. Jag antager för gifvet att också hvarje lepidopterolog hos oss observerat liknande fall - ty de äro icke så sällsynta bland Microlepidoptera - och vilseledts af dem, likasom den engelske entomologen. Sådana småfjärilar äro t. ex. den på häggens blad ofta sittande Penthinia Schreberiana, Cilix spimula, med flere. Larven till en vextstekel (Blennocampa cethiops), hvilken i trädgårdar ofta ligger på öfre ytan af päron- och körsbärs-blad, liknar äfven i hög grad [såsom också mr Jordan anmärker] ${ }^{2}$ ) de färska exkrementerna af vissa făglar och härtill kommer, såsom på ett af Sällskapets pro Fauna et Flora Fennica möten nyss uppgifvits, ytterligare en frän lukt. Också bland skalbaggarne förekomma sådana arter. Så t. ex. är Cryptorhynchus Lapathi ${ }^{3}$ ), denna i hvitt och svart brokiga vifvel, då den lägger sig orörlig med indragna ben, snabel och antenner, till den grad lik fagelträek, som fallit ned på ett blad, att man ej kan önska sig en mera fulländad initation. Men vi ega äfven andra skalbaggar, hvilka på samma sätt fürmå draga in siua ben och antenner i enkom dertill afsedda gropar och rännor och lika envist förblifva i denna ställning, sâ länge de anse sig osäkra. Sådana äro t. ex. Byrrhus pilula och fasciatus, Anobium pertinax (»den enrise med flere. Jag har under senaste sommar kommit till den åsigt att äfven här föreligger en besynuerlig maskering och äfveuledes efter djurs exkrementer. Under en exkursion till Yïnö skärgård i Kimito faun jag nemligen på en af fâr afbetad hårdvall

gör honom ytterst svår att upptäcka. Färgen hos Purnus üfverensstimmer äfven synnerligen starkt med den gyttja, hvarpa denna insekt lefver.

1) I en afhandling inför Rugby School Natural History Society. Wallace, 1. c. pag. 62 .

3) Ent. Monthl. Mag. VIII, pag. 252.

3) I mindre grad imiterar üfven Anthribus albinus figgelträck. 
talrika exemplar af Byrrhus pitula och frapperades dervid af den stora likheten, de erbjödo med färens bredvid dem liggande exkrementer. Likheten kan synas sökt, men är det i sjelfra verket alldeles icke mera, än den för enhvar patagliga likheten emellan fägelträck och de of van omtalade fjärilarne och viflarne. Anobium pertinax, der den ligger orörlig på fünsterposterna i vâra boningshus, har mer än en gång synts mig efterhärma müssens exkrementer. Alla sådana fall, då insekterna ega förmaiga att hastigt indraga antenner och ben eller rulla ihop sig, torde vara att hänföra till den protektiva likhetens område. Insekten kommer derigenom att likna andra såsom födoämnen för fioglar och rofinsekter värdelösa föremâl och blir på detta sätt skyddad för dem. För detta antagande talar yttermera den omständiglıeten att han ofta blifver $\mathrm{i}$ särdeles lionga tider $\mathrm{i}$ denna för honom för öfrigt mindre naturliga stälning, ja att han till och med stundom icke rörer sig det ringaste, äfren on man genomstinger.hans kropp med en nâl (Cryptorhynchus, Anobium "perti$n a x$, »den envise $)$.

2.

Den företeelse inom djurverlden, som är känd under namn af sskyddande likhet s och för hvilken vi i det föregående uppräknat en mängd representanter, har varit föremål för flere framstiende författares meditationer. $\mathrm{Vi}$ hafra redan sagt att vîra dagars naturalhistoria icke àtnöjer sig endast med ett aktgifvande på fakta, utan vill tillika begripa desamma. Hrad är då orsaken till detta märkrärdiga fenomen, hrarmed vi nyss gjort bekantskap? Huru hafva väl alla dessa underbara likheter med omgifvande föremål uppkommit? Se här Wallaces tanke härom.

Vända vi oss till de högre djuren, säger han ${ }^{1}$ ), möter oss genast det bekanta förhållandet, att den hvita färgen är särdeles sällsynt hos de tempererade och varma zonernas däggdjur och făglar. Så finnes det i Europa icke ett enda hvitt däggdjur, icke en hrit făgel med undantag af de fâ arktiska och alpina arter, för hvilka den hvita färgen utgör ett skydd. Och likväl

1) Contrib. to the theory of nat. select., 1. 65. 
finnes hos dessa djur intet anlag att undgå hvitt, ty knappast blifva de tama, förrän af dem uppstå hvita varieteter, hvilka synas trifvas lika väl som de andra. Så hafva vi ju hvita möss, råttor, kaniner, kattor, hundar, hästar, hornboskap, hvita höns, dufror, kalkoner och änder. Fn del af dessa djur hafva redan mycket länge varit tama, andra blott i några fă ârhundraden; nästan i alla fall, då eu djurart fullständigt öfvergâtt till husdjur, hafva hritbrokiga och hvita varieteter uppstatt och blifvit bestående. Men också i det vilda tillstindet uppkomma tillfälligtris hvita rarieteter; sâlunda finner man t. ex. hvita färgförändringar af staren och krakkan, hvita elefanter, hjortar, tigrar, mullvadar; men här förekommer aldrig någon hrit ras, som bibehåller sig.

Det fins ingenting, som bevisar att normalt färgade djur $\mathrm{i}$ tamt tillstand oftare frambringa en hvit afkomma än i vildt; men deremot är det klart, att om i somliga fall rissa färger för en del djur kumna vara till gagn för att skydda dem, kan $i$ andra fall hritt eller en annan i ögonen fallande färg vara $\mathrm{i}$ hög grad skadlig för dem och i de flesta tillfällen fürkorta deras lif. En hvit kanin blir hökens säkra byte och en hvit mullvad kan ej undgå ugglans raksamma öga. Likaså torde för ett rofdjur hvarje afrikelse frin de färger, som büist egna sig för att dölja detsamma, öka svårigheten att förfölja dess rof och sålunda sätta det $\mathrm{i}$ ogyusammare förhâllanden än dess kamrater samt efter några år förorsaka dess död af svält. Men så snart en djurart utbreder sig från en tempererad till en högnordisk trakt, förändras naturligtvis förhâllandena. Under en stor del af aret och just på den tid, då kampen für tillvaran är hårdast, är hvitt naturens herskande färg, och mörka färger skulle då vara mycket $\mathrm{i}$ ögonen fallande. De hrita varieteterna hafva di öfrertaget och kumna undgi sina fiender eller öfverrumpla sitt byte, under det deras bruna kamrater blifva uppätna eller svälta i hjäl. Och di det är en af naturlagarne, att »lika frambringar likar, sì blir den hvita rasen smâningom bestående. On nemligen äfren derefter mörka rarieteter skulle uppträda, dö de snart ut, emedan de ej passa till omgifningarna. I alla händelser blifra 
de afarter vid lif, som bäst äro lämpade efter de lifsvilkor, under hvilka de lefva.

Vi hafva här en illustration, fortsätter Wallacé, pâ de enkla, men verksamma medel, genom hvilka djuren kunna bringas till öfverensstämmelse med den omgifvande naturen. Den obetydliga föränderligheten hos de enskilda arterna, som vi vanligen betrakta sîsom blott något tillfülligt eller abnormt, hrilket vi knapt anse vara värdt vâr uppmärksanhet, synes vara grundvalen för alla dessa märkvärdiga och harmoniska likheter, som spela en sâ vigtig rol i natureus hushållning. Visserligen är denna föränderlighet $\mathrm{i}$ sig sjelf mycket ringa, men den är dock allt som behöfves, emedan äfven de vexlingar i de yttre förhållandena, dem ett djur blir underkastadt, i allmänhet äro mycket lângsamma. Hade dessa förändringar hastigt för sig gått, skulle resultatet ofta hafva blifvit artens utdöende; men det är en allmän sats att geologiska förändringar och förändringar i klimat försiggå lângsamt, och de ringa, men oafbrutna variationerna i färg, form och struktur hos alla djur hafva frambragt individer, lämpade för dessa förändringar, och hvilka hafva blifvit stamfäder för modifierade raser.

En snabb förökning, en svag, men oupphörlig förändring, bevarandet af det ändamålsenliga, - dessa äro de enkla lagar, hvilka alltid hålla den organiska verlden i harmoni med den oorganiska och med sig sjelf. Dessa äro de lagar, hrilka Wallace anser hafra frambringat alla fall af skyddande likhet, på hvilken vi ofvan anfört så många exempel och pâ hvilken vi skola blifva $i$ tillfälle att $i$ det följande anföra änuu andra af vida mer invecklad art.

De mest underbara af de redan omtalade äro onekligen de fall, dá iusekteu icke blott till fürg, men äfven till skapnaden efterhärmar rextdelar, såsom t. ex. imitationen efter särskilda blommor, qvistar, o. s. v. Denna fullständiga lämpning efter den omgifvande naturen torde först ytterst småningom hafva uppstått, steg för steg, genom ändamålsenliga förändringar i färg, form och skapnad, instinkt och lefnadsvanor. Ätföljdes en sådan förändring icke tillika af en oändamålsenlig $i$ en annan rigt- 
ning, sâ förefunnes ju alla skäl för att den skulle blifva den ïfverlefvande.

Per'soner, som icke lärt sig att tïnka öfver naturen eller icke haft nog simne för observationer i densamma, hafva trott sig med en enda invändning kunna kullkasta denna Wallaces teori. Om dessa lagar verkligen skulle gälla, säga de, hrarför finnes det dá djur, som hafva i ögonen fallande färger, de der lätt röja dem för deras fiender, huru skall man väl förklara tillvaran af alla dessa briljanta faglar och lysande insekter, hvilka sâ talrikt förekomma öfver hela verlden? Det är nödvändigt att vi egna ett ögonblicks uppmärksamhet ât detta inkast, förr än vi gå vidare.

I mer in ett fall skall det visa sig att den såsom det kan synas till en början oförklarliga färgen dock vid en närmare undersökning risar sig vara protektiv. Jag erinrar mig härvid flertalet af de pá barrträden lefvande hemiptera. hvilka, till huru vidt âtskiljda grupper de ïn höra, dock alla förete en egendomlig rödgul, nâgon gâng rödbrun fürg, ofta beledsagad af nog stark punktur och glans. Denua för alla dessa arter gemensamma fürg kan icke gerna vara blott en tillfällighet, lika litet som den pâ nâgot sätt synes stå i något samband med den mörka grönskan hos nämnda träd. Sistlidne sommar tror jag mig emellertid hafva fumnit en förklaring på densamma. Jag uppfödde nemligen dâ en mängd barrträds hemiptera, hrarvid jag fann att dessa rödgula arter mestadels uppehöllo sig, icke på barren, utan pâ de rödgult fjälliga ungskotten nf träden.

I en särdeles intressant uppsats : A theory of bird's nests ( $i$ Contrib. to the theory of natur. select. " p. 241) har Wallace frambållit den omständighet, att $i$ allmänhet de faglar, hvilkas honor äro matt färgade och hafva en med omgifuingarne mera hopsmältande teckning. bygga s. k. öppna bon, hvaremot de fâglar, hos hvilka honan, sâ räl som hanen, har lifligare färger, häcka i dolda bon, d. v. s. oftast i ihâliga träd, i murar, eller ock i bon, hrilka äro sâ slutna, att fágeln nnder häckningstiden helt och hâllet blir osynlig för fiender. Frin denna sats synes emellertid bland de till vîr fauna hörande faglar den vackra sidensvansen (Bombycilla garmla) göra ett undantag, i 
det könen här äro nästan lika fürgade och de eleganta röda raxlika spetsarne pâ vingfjädrame nästan och stundom fullkomligt lika tydliga lıos honan som hos hanen. Likväl bygger demna fågel ett öppet näste och en person, som ser densamme skall ej gerna medgifva att han lemnar något stöd för Wallaces teori. Men man mâste betrakta honom icke $\mathrm{i}$ ett museum, utan ute $\mathrm{i}$ naturen; och man skall finna att han $\mathrm{i}$ sjelfva rerket genom sin färg blir sa skyddad som nâgon fágel kan blifva. Han häckar endast under mycket höga latituder och nästet, placeradt i furorna, är bildadt hufrudsakligen af lafrar. Nu äro de fina grå- och ask-lika samt purpurartade färgtonerna på hufvud och kinder jämte det gula på vingar och stjert, färger, hvilka fullkomligt harmoniera med färgerna af särskilda arter lafvar, under det de lysande röda spetsarne fullständigt representera de karmosinröda fruktifikationerna hos en allmän laf, Cladonia coccifera. Dá făgeln sålunda sitter $\mathrm{i}$ sitt näste, framställer honan alls ingen färg, hvilken vore främmande för det material, hvaraf detta är hopsatt, och de särskilda färgerna äro ordnade enligt ungefür samma förhållanden, i hvilka de förekomma i naturen. Pâ äfren ett kort afstând är făgeln nästan omöjlig att särskilja frân det näste, hrari han sitter, eller frín en naturlig gyttring af lafvar och blir derigenom fullkomligt skyddad.

I andra fall kunde man invända att fagglar finmas, hos hvilka honan eger en mera brokig och lysande drägt än hanen, och dock borde ju just honan rara protegerad, dâ pâ lienne äggens utkläckning beror. Sâlunda äro båda könen till Phalaropus fuTicarius under vintern nästan fullkomligt lika hvarandra, medan honan om sommaren erhâller en mera glädtig och lättare skönjbar bröllopsskrud. Men också detta inkast faller snart, blott man undersöker fâgelns naturalhistoria, och förvandlas, äfven det, $\mathrm{i}$ stället till ett ytterligare bevis för Wallaces asigt. Här eger nemligen det märkvärdiga förhâllande rum att det icke ar den mera lysande honan, utan den mattare färgade hanen, som rufvar äggen, liggande pâ dem, der honan lemnat dem pâ den bara marken. Liknande torde fallet vara med en annan art (Endromias morinellus), hos hvilken samma omvända förhâllande, hrad beträftar: färgen, eger rmm emellan hane och houa. 
Vi finna sâlnuda af det ofvan anförda att mânga fall, hvilka synas oss stridande emot Wallaces teori, tvärtom funnit sin förklaring ur denna, så snart man trängt djupare in i frågan. Helt visst skola äfven minga tropiska insekter, hvilkas lysande färger nu syuas oss allt annat än protektiva, visa sig sasom imitatoriska, så snart dessa djurs lefuadshistoria och deras närmare förekomstsätt bland den heta zonens mangfürgade vextverld blifvit närmare utredda.

Men man må för öfrigt ingalunda anse att alla djur mâste vara skyddade genom en färglikhet, sådan som den, för hvilken blifvit redogjordt. Det kan ej annat än förvâna att äfven frân en och annan retenskapsmans sida en dylik invändning blifvit gjord, som denna: »om nu alla dessa påpekade former vore utmärkta af en skyddande färglikhet, hvarför hafva då icke alla djur blifvit sâdana?" Det är klart, att blott de djurarter kunnat fortbesta, hrilka på ett eller anuat sätt luallit sig uppe i den stora kampen för tillvaran, i striden med fiender och jämlikar. Men det borde äfven för hvarje tänkande och med observations förmåga begâfrad menniska vara lika klart att medlen härför äro mângahanda, att djuren på en oündlig mängd olika sätt kunna erhâlla sin föda och undfly sina fiender och att deras olika lefnadsart och instinkter alltid äro lämpade efter deras lefuadsvilkor. Igelkotten har en beväpning, som skyddar emot de flesta djurs angrepp. Nord-Amerikas stinkdjur utsprida kring sig en för andra djur olidlig lukt, som hâller dem pâ afstâud; bäfvern döljer sig i sina solida boningar. En stor mängd făglar äro i symnerhet sâsom ägg och ungar utsatta für fara och det är derför vi inom denna klass ega sâ mânga och sâ mângskiftande exempel på de mest märkvärdiga bon, upphängda genom konstiga inrättningar i spetsarne af ytterst böjliga grenar, o. s. v. Då äggen icke äro sâlunda skyddade finna vi mycket ofta äfren hos dem skyddande färglikhet; sâ t. ex. imitera äggen till en stor mängd vadare och simfáglar alldeles mästerligt de prickiga och af vágorna slipade smâ stenarne pâ hafsstränderṇa, ibland hvilka de äro lagda ofta utan vidare underrede.

En synnerligen rigtig faktor för flere arters bevarande är vidare det förhâllande, som eger rum emellan antalet ägg och 
de lifsvilkor, som möta. Sålunda äro äggen talrika i synnerhet hos sådana arter, hvilkas afföda lätt är utsatt att förstöras. De flesta hönsfăglar, hvilka, såsom kändt, lägga äggen i ett konstlöst rede på blotta marken, producera ett vida större antal sádana, än hrad vanligen är fallet med fåglar, hvilka kläcka i egentliga bon. Den på individer troligen rikaste af alla făglar, fregattfågeln, hvilken häckar på de mest otillgängliga klippor ute $\mathrm{i}$ hafvet, lägger âter ett enda ägg.

Bland insekterna eger förmodligen samma förhållande rum; af mycket intresse vore att utreda proportionen emellan antalet ägg hos de på ett eller annat sätt skyddade arterna och hos dem, hvilka synas sakna ett sådant skydd.

»Skyddet《 är för öfrigt af mångfaldig art inom särskildt denna djurklass och vi hafva redan anfört att endast tanklösheten eller en bristande iakttagelse kan framkasta den invändning emot teorin om den protektiva färglikheten, att arter förekomma med äfren i ögonen särdeles väl fallande färger. Sïdana arter äro ofta på annat sätt bevarade för en stor mängd fiender. Vi hafva ofvan nämnt stinkdjuren inom vertebratklassen; vi kunde tillägga åtskilliga genom en frän lukt eller afsöndring utmärkta padd-arter. Samma medel förekommer äfven ganska ofta bland leddjuren. Sålunda ega de flesta hemiptera. hvilka hafva mera skönjbara färger, en särdeles stark och obehaglig lukt, under det deremot de arter, hvilka sakna en sådan, mycket ofta förete en protektiv färglikhet med näringsplantan. Flere skalbaggar fürhâlla sig pã samma sätt. Så t. ex. den lysande guldsmeden, Cetonia, si̊ $\mathrm{i}$ synnerhet de gul- och svartbrokiga dödgräfvarena, Necrophori, hvilkas lukt är så stark, att de $\mathrm{i}$ flere decennier efter sin död, uppstuckna $\mathrm{i}$ en insektlåda, ännu bibehâlla samma stank, hvilken till en början kan meddela sig hela samlingen. De brokiga arterna af slägtet $\mathrm{Cocci-}$ nella (nyckelpigor) kunna äfven afsöndra en föga behagligt luktande vätska. Äfven några fjärilar ega samma förmåga att utsprida lukt. Detta är t. ex. fallet med hanarne af Doritis mnemosyne, hos hvilken atminstone under parningstiden framsipprar $i$ spetsen af abdomen vid det egendomliga hornartade bihanget 
en gul, klibbig, starkt luktande vätska ${ }^{1}$ ). Bland Myrioporler och Phalangier förekomma äfren illa luktande arter. Också larver, som ega en dem röjande färg, skyddas genom obelıglig lukt. De svarta eller hvita larverna af flere Chrysomelider bland skalbaggarna lata sålunda vid beröring utsippra från kroppens sidor en särdeles starkt luktande rätska. Sadana skarpa vätskor skydda för öfrigt flere insekter. Majbaggen, Melö̈, afsöndrar i knävecken en ymuig gul väiska, som verkar blassdragande, och af den metalliskt gröna spanska flugan, Cantharis, är hela djuret, sisom kändt, sådant. Den myrorna utmärkande myrsyran afhâller utan trifvel många fagelarter från att lifnära sig af dessa insekter. Rofskalbaggarne (Carabirle), hvilka ofta hafva metalliska färger, utspruta mot sina fiender en vätska, som dá den berör några ädlare partier, framkallar stark sveda. Flere arter ega dessutom en egendomlig lukt ${ }^{2}$ ).

En stor mängd insekter inom steklarnes ordning äro beväpnade med en stickande gadd och just inom dema ordning förekomma särdeles brokiga arter. Andra, sâsom t. ex. Staphyliniderna bland skalbaggarna, gifra sig ett skydd genom de ställningar de intaga. Genom att sålunda böja uppåt sin smala bakkropp skrämma de icke blott andra djur, men äfven barn, hvilka helt naturligt inbillas att dessa insekter ega en gadd. Jag erinrar mig sjelf detta från de första tider, jag började samla insekter. Äfren de egendomliga stälnningarna och rörelserua hos flere Sphinx-larver, hvilka slå den halft upprätta kroppen än àt ena, än at andra sidan, rerka förmodligen skrämmande på fienden.

Ytterligare andra insekter kumna vid hotande fara framskjuta ur kroppen hittills inom denna dolda utskott, såsom de

1) Ändamålet med de af Miiller nyligen beskrifna doftfjällen ( Duftschuppen a) hos en mängd fjärilar synes icke sti i samband med protektionen, utan nästan afgjordt, enligt hvad alla iakitagelser gifva vicl handen, hänföra sig till möjliggörandet af könens uppsökande af hvarandra. I de flesta fall :ir den genom dessa fjall frambrytande doften belıaglig.

2) Anmairkningsvïrd är bombarderbaggen (Brachimus crepitans), hvilken utslïpper en gas $\mathrm{i}$ form af en liten rök och âtfiilju al tydligt förnimbar knall. 
röda eller gula tentakel-lika utspri̊ngen frân nacken pâ åtskilliga Papitio-larver. Atminstone los P. machaon atföljes detta framskjutande af nämnda tentakler af en ganska förnimbar lukt.

Flere insekter hafva ett ytterligt hairdt skal. Sa äro täekvingarne hos mânga af de ofta synnerligen brokiga viflarue, Rihynchophorema, sî hårda, att de kumna genomstingas med insektnål först efter det de genonborrats med en hvass pemnkuif. Denua hârdhet gör dessa insekter onjutbara och är ett godt skydd mot fienden. Liknamde är fallet med de särdeles grant metalliska Chrysididerno bland steklarna, livilka rulla sig tillhopa till en boll, som i hårdhet föga stâr efter en rerklig metall-kulas. För öfrigt gömma flere iusekter sig sjelfva i blomkalkarne, i barkspringor, pâ bladens undre sida, o. s. v., eller öfverpudra de sig med pollenmjöl, o. d., som bidrager att dölja dem ${ }^{1}$ ).

En suabb flygt gyunar ganska många arter och det starkt surrande eller brummande ljud, hraraf demna ofta âtföljes, bidrager mâhända äfren att $i$ sin mân hâlla mângen fiende på behörigt afstind. Sjelfva sättet att flyga är ïfren pâtagligen af betydelse för atskilliga species. Enhvar kïmuer trollsländornas hastiga rörelser ïn at ett håll, än helt plötsligt ât ett annat, och livarje samlare af dessa djur vet huru ytterst svåra de äro att fanga i flygten samt kan väl förestïlla sig huru lätt en sländı skall kumna uttrötta en honom förföljande fâgel. Till och med en sâ snabb flygare, som svalan, har svirit att gripa en sâdan insekt. Flere skalbaggar, t. ex. guldsmeden, Cetonia, utmärka sig genom en stïndigt i zigzag vaggande flygt, hvarigenom de lättare undga fíglarne, de der icke kuma göra lika korta slag at hvardera hållet.

Stundom synes det sâsom om karakterer, hvilka, sionom det kunde tyckas, äro allt ammat äu skyddande, dock $\mathrm{i}$ sjelfva verket bidroge till individens bevarande. Silunda hafva flere stora fjürilar af till exempel slägtet Propilio särdeles vida och breda vingar med fürger; som ingalunda dölja den. Men man har ol, serverat - och man ser det ofta iifven pâ vil finskia $P$. ma-

1) I nigra fall foirekonmer en imitation efter en dylik pudring; si 1. ex. bland vithme inom slightena Ciomes och Lixus. 
chaon - att făngade exemplar ej sällan visa pî mânga siitt hrutua eller likasom genomstuckna ringar, sisom hade de blifrit litua aif făglar, hrilka angripit dem, men frân hrilka de âtèr sluppit lüsa. Hade vingarne icke egt demna storlek, sâ skulle fâgeh lütt hafra fătt tag uti nagon mera lifsforlig del och vingarnes utsträckning måste derför betraktas sassom i detta hänseende, om iffen indirekt, nyttig för djuret.

Af sïrdeles stort intresse ïro de undersökningar, som blifvit företagna öfver betrdelsen af fürgerua hos fjäril-larver. $\mathrm{Ti}$ vilja efter mr Wallace något omstaindigare redogüra für dessa. En stor mängd larver äro. sisom vi i fïregiende afilehning visat, gröna eller bruna, i det närmaste liknande de föremâl, pá hrilka de lefra, andra innitera mästerligt stickor, grenar, o. s. r., frân hvilka de orörligt strïcka sig ut, sâ att de fullkomligt likua en af dessa. Men ett ingalunda mindre antal äro sil briljant fürgade och teckuade, att de redan pâ ett hetydligt afstand lysa i ̈̈gonen. Kändt ir att fjüril-larrer ingi i en högst rïsendtlig grad bland fáglarnes födo-ïmmen. Srârt är derfür att första huru en del af dem kumna hafia sidana klara och lysande färger, hrilka likasom särskildt göra dem synliga. Wallace antog derför att, likasom en del larver roro skyddade grenom protektiv färgimitation, andra âter af hin och taggar, sâ mâste äfren dessa briljanta färger hos resten pî nagot sätt vara af nytta för djuret. Han erinrade sig att vissa fjärilar slukas med symnerlig aptit af faglar, medan ater andra ratas och airo dem misshagliga. Men denna omstiudighet ensam, att de nemligen rore osmakliga, skulle icke blifra larren till siirdeles gagn, emedan hennes tumna hud och finn kroppsbyguad redan humue blifra skadad, sí suart hon en gâng kommit in i fâgelns mun, hrarfür det föga rore hemne till gagn, om hon üfren sedan iter bortkastades. Vissa konstanta och lätt synliga märken vore derfür nödriindiga tecken für fäglarna, $\mathrm{i}$ det de rarnade dessa att angripa onjutbara arter, och en mycket gramn firg rore $\mathrm{i}$ sidant afseende sürdeles limplig. Wallace föredrog denna frága iuför Entomologiska Societeten i London den 4 mars 1867 och uppmanade till observationer ofrer densamma.

Tra bekanta engelska entomoluger hafia lemmat sraret 
derpâ. Ar 1869 meddelade nemligen mr Jenner Weir en rärderik serie af iakttagelser, gjorda under flere år i hans aviarium, som innehöll följande mer eller mindre insektätande fâglar: lärkfalk, gulfink, bofink, korsnäbb, trast, grönsiska, trädlärka, med flere. Han fann att hâriga larver helt och hâllet försmâddes ${ }^{1}$ ); flere särskilda arter blefvo fullkomligt orörda af hans faglar och fingo ostraffadt dagarna igenom krypa af och an i aviariet. Trå arter taggiga larver blefvo likaså bortkastade. Men i bâda dessa fall anser mr Weir att det är smaken och icke hârigheten eller taggigheten, som gör larverua onjutbara för fäglarna. Och dertill har han full orsak, enär mycket unga exemplar af en hârig art likaledes försmåddes, ehuru alls inga hâr ännu voro utvecklade, samt emedan de släta puporna af ofran ontalade fjärilar förkastades äfren sâ väl som de hâriga eller taggiga larverna.

Hans nästa experiment företogs med dessa släta grant färgade larver, hvilka aldrig dölja sig sjelfva, utan tvärtom redan pâ hâll väcka âskådarens uppmärksamlet. Sådana äro t. ex. larverna af stickelbärsfjärilen, Abraxas grossulariata, hvilka äro fläckiga i hritt och svart, af Ditoba coevuleocephala, hvilkens larv är blekt gul ned en bred blã eller grön sidostrimma, af Cucullia rerbasci, som har en grönaktigt hrit larv med gula band och svarta fläckar, och slutligen af Anthrocerc filipendule, hvilken i detta utrecklings stadium är gul med srarta fläckar. Dessa larver gâfvos ât fâglarne på olika tider, stundom tillsamman med andra, hvilka glupskt förtärdes, men dessa ratades fullkomligt och fingo i fred krypa omkring, tills de dogo.

Nu gjordes försök med mörkfärgade larver eller sådana, som utmärka sig genom skyddande färglikhet. Resultatet af talrika experiment i denna väg är $\mathrm{i}$ korthet sålunda affattadt af mr Weir: "Alla larver, hvilka uppträda nattetid, hvilka äro mörkt färgade, med mjuk, köttig kropp och glatt hud, ätas med största begärlighet. Hvarje grön larv är äfvenledes synnerligen omtyckt. Alla Geometre (mätare), livilkas larver likna qvistar,

1) Dock fürkasta icke alla fäglar håriga larver. I magsücken af güken har jag en gång funnit huden af flere sådana. 
der de stâ ut frân vexten, utstrückta pâ sina amalfötter, hlifra utan undantag förtïirda .

Mr Butler, en vid lnitiska musenm anstiald lepidoptero$\log$, lar äfven meddelat resultaten af sina observationer med hänsyn till ödlor, grodor och spindlar, hrilka noggrant öfrerensstämma med mr Jenner Weirs. Tre gröna ödlor (Lacerta viridis), hrilka han hâllit under atskilliga âr, voro mycket rofgiriga och âto all slags föda frôn citron till spindlar, flugor, bin och fjäril-larver. Men nâgra larver och fjürilar fumuos, hvilka de gropo endast för att omedelbart derefter ater lâta dem falla. Bland dessa voro larven till Abraxas grossulariata och den fullt utbildade fjärilen af Anthrocera filipendula. Dessa angrepos visserligen till en början, men blefvo snart en vämjelse för öıllonna och lemuades sedan alltid orörda.

Härefter uppföddes grodor med larver ifrân trädgarden; men tvâ af dessa, den redan förnt ommämnda stickelbärsfjuirilens och w-fjärilens, Halia vavaria, som är grön med i ägonen fallande hvita och gula strimmor samt svarta fläckir, blefvo städse försmâdda. Dá dessa larver först erbjödos grodorna, hoppade de ifrigt efter dem och togo dem i munmen, men senare hade de redan blifvit varnade och suto blott med öppen mum och rullande tunga framför de vämjeliga natbitarne.

Med spindlarne egde detsamma rum. Dessa bada larver' sattes gâng pâ gâng i de nät, hvilka beboddes af Epeira diadema, den vanliga kors-spindeln, samt af en Lycosa-art, men försmâddes utan undantag.

Mr Butler har iakttagit ödlor stridande med och slutligen uppätande humlor, äfrensom grodor, hvilka jagat efter över deras hufvud flygande bin, dem de bemägtigat sig och nedsväljt, utan att bry sig om dessas stygn. Häraf synes att en oangenäm lukt eller smak är ett rerksammare skydd för vissa litt skönjbara fjäril-larver eller fjärilar, än till och med det, som erbjudes genom förmâgan att sticka.

Dessa tvemue forskares undersökningar hafva sâlunda fullkomligt bestyrkt den liypotes, som mr Wallace ar 1867 uttalade angâende den förmodligen räitta förklaringen af de brokiga och lysande färgerna hos en mängd fjäril-larver. Dessa fürger, 
hrilka visserligen icke äro pá det minsta vis imitatoriska, äro dock pri sitt sätt, äfren de, protektiva, ithy att de faglar, ödlor, groodor, ı. m., som redan en gâng lärt sig kämna dessa gramut larvers obehagliga smak, just i nämuda fürger och teckningar finua ett memento att icke röra dylika larver. Den svârighet, som dessa erbjudit at WVallaces teori för den protektiva fürorlikheten, ïr sâledes härigenom upphäft.

Vi fimma sâlunda att $\mathrm{i}$ en mycket stor mängd fall, dî en skyddande färgimitation icke utmärker en art, hav hon nâgon annan omständighet att tacka för sitt forthestând, vare sig da en ytterst riklig propagation, snabb eller i öfrigt säiregen flygt, ntsprutande af svidande eller stinkande väitskor, vidrig lukt eller smak, eller aunat dylikt. Den gjorda invändningen att inga djuren röjande färger borde i naturen förekomma, ifall man en gâng antager teoriu om den protektiva färomitationen, sâdan den af IVallace framstälts, blir sâledes utan all betydelse. Demna skyddande färglikhet är nemligen blott, sásom sagdt, ett af de nânga medel, naturen använder för att vidmagthâlla den lefvaude tillvaran af sina organismer. Och klart är äfven att intet fimnes, som hindrar flere af de ofvan pâpekade orsakerna till arternas forthestând att i vissa fall samverka. En protektivt färgatd art hehöfver derför ingalunda nödvändigtris sakna en fienden afhâllande lukt eller smak eller förmâgan att sticka, o. s. v. Nagot dylikt kan fordras endast af korttänktheten och en sâdan fordran förringar derför icke i minsta grad värdet af mr WVallaces teori. Genom ett närmare iakttagande pâ djurens och lufvudsakligen insekteruas lefuads historia ökas fortfarande hevisen för densamma, ju oftare vi kunna pâvisa att grant och brokigt färgude arter ega i andra omständigheter ett hittills obeaktadt skyddsmedel. Och mest af allt talar just det för samningen af en hypotes, att flere och flere fall upptäckas, som bestyrka densamma och lıvilka deraf kumna förklaras, äfveusom att skenbara motsägelser afslöjas och i stället komma att $\mathrm{i}$ sjelfva verket vitna för den i frâga varaude hypotesen. Och WVallaces hypotes kan redan med skäl hojas upp bland teoriernas antal. 
Redan länge hafva entomologerne haft sig belant att det finnes ett antal insekter, lwilka visa en stor yttre likhet med andra arter, hörande till fullkomligt skilda slägten, familjer och till och med ordningar. Sürskild uppmairksambet i detta hänseende förtjenar en art grüshoppa (Condylodera tricondyloides) frâu Filippinerua, hvilken till den grad liknar en skalbagge (Tricondyla) af Cicindelidernas familj, att en sâ erfaren insektkämmare, som professor Westwood, uppstälde den i sin samling bland nïmnda skalbaggar ouh behöll den der en lâng tid. inuan hau faun sitt misstag!

Emellertid har man ansett denna inom insektverlden tätt och ofta âterkommande likhet, denma sanalogi«, som man lisllat henue, beroende af nagon okänd och outgrundbar lag, nagot natursystem « eller nâgon »allmän plau", som ledt skaparen, dá han gifvit form och fürg at alla dessa myriader, som möta oss i de lägre djurens rike. Och dermed har man âtuöjt sig. Blott i ett enda fall har nyttan af en sidan likhet med andra insekter varit sâ omisskännelig, att mau uödgats erkänma att den tjenat ett bestämdt och tydligt mâl Bland flugorna finnes nämligen ett slägte, Volucella, hvars arter intränga i humlormas bon för att derstädes lägga sina ägg, livarefter de ur dessa framkläekta larverna lefva af humlornas afföda. Dessa Hugor äro pá ett förundransvärdt sätt lika just de Bombus-arter, i hvilkas nästen de föra sitt parasitiska lif; och redan Kirby och Spence, författarene till det pâ sin tid sâ utmärkta arbetet Introduetion of the entomology «, amse demna likhet uttryekligen tjema till att skydda flugorna för humlornas anfall; och i sjelfva verket ligger detta faktum sâ klart $i$ dagen, att det knappast af nâgon skall i frâga sättas.

Men en dylik härmning efter andra arter till form och färg, en dylik sâ kallad »mimiery" förekommer, sâsom redan blifvit sagdt, ingalunda sällsyut bland insekterna, ehur'u det varit först vâra dagars naturforskare förbehâllet att närmare utreda flere af גessa fall och följa dem i deras detaljer. Och genom ett omsorgsfullt studium, särdeles af tropikermas formrika insektverld, 
har man äntligen kommit derhän, att man kummat hänföra fenomenen till best:imda lagar, liärflytande ur den grundlag, att det ändamálsenligaste upprätthâlles i naturen och att »de gynnade raserna bevaras i kampen för tillvaran«; och ur demna har man kunnat gifva dem deras, sassom det synes, fullgiltiga fürklaring.

Vi skola, enligt Wallace, innan ri meddela några exempel, güra lïsaren uppmürksam på de slutsatser, till hrilka nümude fürfattare kommit, och livilka :̈nnu veterligen icke motsagts af nigot enda faktum.

Den första lyder, att $\mathrm{i}$ ett särdeles öfverrägande antal fall de djurarter eller grupper, som likna hraraudra, bebo samma land, samma trakt, ja till och med i de flesta fall finuas tillsamman pá en och samma fläck.

Den andra lagen är den, att blott rissa grupper, rika pai arter och individer samt oftast företeende ett cller ammat slag af särskildt skydd, äro föremål fär en dylik efterhärmuing.

Den tredje slutligen innebär att le arter, som äro $\gg$ mimiska", d. r. s. likna dessa herskande grupper, deremot sjelfra äro jämförelseris fattiga pá indirider, ofta till och med mycket sällsynta.

Ned dessa fakta för ögonen rilja vi nu gâ att inom de olika insektordningarna betrakta nâgra siirskilda fall af en sâdan "fürklüidnad eller »maskering", och skola ri härvid, sassom hittills, göra detta med speciel hänsyn till nordens fauna. Ehnru risserligen härigenom mânga och bland annat onekligen do intressantaste och mest öfrertygande exemplen på »mimicry « mâste af oss fürbigâs, torde dock ie fall, som kunna framdragas äfven hos oss, göra till fylles; och dâ många af dem kumna af en lıvar, som intresserar sig för insektrerlden, lätt nog i naturen observeras, torde det äfren ur denna sympunkt vara lämpligare att sålunda inskränka vârt program. Det kan för öfrigt icke blifva vâr afsigt att uttömmande behandla ämnet ens i denna form, lika litet som vi i de föregaiende afdelningama af vair uppsats kumnat göra nagot ansprak pâ fullständighet. Nya fall af "protektic likhet" möta ständigt den med uppmärksant 
öga $\mathrm{i}$ naturen vandrande entomologen, och äfven siodana af en i allo genomfürd smaskering " skola helt visst âr för âr upltiickas oukså inom vår fauna.

W allace börjar sin bevisföring med fjärilarnes ordning, Lepidoptera. Inom denna, sâ väl som inom de öfriga, hafia vi att göra âtskilnad emellan de fall, dâ hit hörande insekter imitera arter af samma eller af skilda ordningar. Exenpel på det fürra af dessa förekomma ytterst talrika i de tropiska regionema ${ }^{1}$ ). Deremot kämmer man blott ett fill från nordens famma. Mr. Stainton har vämligen observerat att af en Hlock unga kalkoner, som glupskt slukade alla andra nattfjürilar, dem han under en natt infangat, den ena efter den andra grep, men âter kastade ifrân sig en viss hvit art, Spilosoma menthrstri, som tillfälligtvis faus ibland dessa. Nümnda fjärilar äro således allt för illa smakande för att ütas af fäglar och detta bekräftas äfven af mr Jenner WVeir', som fann att desamma förkastades af bofinkar och andra smáfiglar i hans aviarium. Demna fjäril är särdeles allmän och har en redan på hall synlig hvit färg. Pâ samma ârstid, under samma timmar pâ dygnet uppträder ïfven en annan art, Diaphora mentica, hvilken erhallit sitt artnamn, »den lögnaktiges, förmodligen just derför att hou i förvillande grad liknar sî vail till storlek, som utseende den omtalade Spilosoma, men hou är betydligt sällsyntare än denua.

1) Si imiteras Syd-Amerikas Heticonider af Nymphalider och Lcplulis-arter, de med Heliconidema beslïgtade Danuiderna och Acraeiderma i gamla verldens heta zon efterapas till form och lärg af Papilio- och Diadema-arter ofta ïnda derhän, att slickliga entomologer ansett den ena arten sissom den andras hona eller rent af förvexlat dem med hvarandra; Heliconider, Danaider och Acraeider äro skyddade genom en egendomlig lukt och smak, som gör dem obehagliga och osmakliga för foglarne, likasom für ödlor och rof-flugor. De efterhärmade arterna äro mycket allmïnna, de imitemule deremot sällsynta; men bida füreliomma vanligen pá samma plats och flyga till och med på samma sätt. Hügst egendomliga äro några Papilioarter, t. ex. P. memnon frin Sumatra, $P$. andragens frain norra Indien, m. Al., af hvilka haname och en del honor äro hvarantra lika, medan öfriga individer af det senare könet helt och hâllet afvika till form och färg och mïsterligt efterapa andra, fömodligen skydelate Papilio-arter, sisom $P$. coom och Doubledayi. 
Erinrar sig läsaren hvad tidigare blifvit framhallet $\mathrm{i}$ afseende a fjäril-larver med lysande färger, så behöfva vi här blott uppmärksamma att den luvita färgen är af alla onekligen den farligaste just för en nattfjuril, emedan den liittast synes i nattens mörker; eudast fjarilar, som ega ett anmat skydd, sâsom t. ex. den för Spilosoma karakteristiska lukten eller smaken, kumna lättare undgi fienden och blifva tahrika. Och ett skydd i sitt slag innefattas äfren deri, att en art helt och hallet efterapar till storlek, form, fïrg och sätt att flyg:ı ett salunda protegeradt species. Detta är fallet med Diaphora mendica, som sammolikt i denna sin maskering har ett fripass. Wallace syues för öfrigt böjd att antaga att alla hvita och talrikt förekommande nattfjärilar ratas af faglarne. Experimenter häröfver vore af icke ringa intresse och skola mâhünda uppdaga att vi ega ännu flere lepidoptera, som imitera andra arter af samma ordning, än denna enda, hvilken vi nu äro i tillfälle att anföra. För landtbrukáren eller prestmannen på landet kunde dylika smâ försök öfver ¿imnu oförklarade företeelser inom naturen vara en förströelse pá samma gång de i sin mán bidroge till att sprida ljus öfer en vetenskaplig fråga.

Fjärilar, hvilka efterapa insekter af amman ordning, förekomma deremot i större autal inom vir fauma. Deuna imitation torde emellertid vara inskränkt till en förkkaidnad uteslutande efter arter hörande till steklarues ordning, Hymenoptere. Nyttan af denna mask ger sig vid nágon eftertanke lätt tillkänna. Alla de imiterade steklarue höra till gruppeu Aculeata eller "gadıfồrsedda《. Elıuru väl en del fâglar, sâsom töruskator, Hugrsuappare med flere icke sky att augripa iffeu dessa insekter och ehuru man sett grodor och andra krïldjur jaga efter och förtïra bin och getingar, torde dock demna deras förmiga att sticka skydda dem för eu stor mängd fiender. Det ïr till Setiidernas familj, som de maskerade fjürilarne nästan santeligen höra. Sá hafva vi Setia scoliiformis, spleceiformis, formiciformis, ichnemeniformis, Sphecia crabroniformis, Trochitia "piformis, Macroglossu fusiformis och bombyliformis, med Here. Demna sistnämuda likuar ytterst noga hanen af deu allmänna träigândshumlan, Bomlus hortorem, och frambringar äfou un 
der sin flygt, såsom jag för nâgra dagar sedan var i tillfälle att iakttaga, ett brummande, surrande läte, snarlikt det af en humla, lvilket i srmmerhet blir starkt, on djuret hailles i något kïrl eller slutet rum; ett dylikt, Hygten âtfïljande läte är för resten naigot fullkomligt frümmande för fjüirilarnes ordning, och imitationen efter steklarne (humlorna) gâr här sâledes ännu längre än blott till form och fïrg. Trochitia aniformis liknar sa myeket en geting, att personer, som sett heme i min samling, utan betänkande hallit henne för en sâdan; och mr Jenner Weir anför om den, likaledes sasom en geting färgade Sphecin crobroniformis att hon nycket mera liknar dema stekel ute i naturen in $\mathrm{i}$ ett museum, och att $\mathrm{i}$ symerhet hennes saitt att föm vingarne fullkonnar illusionen. Ïnnu en liten art, Setic limmliformis, som nnder sommaren ses flyga öfver Spirea och andra hä̈ckar, liknar en liten srart, gublbandad geting, Orynems simutıs. Hela denna familj, Setridr, imnefattar de allra vackraste exempel pá maskering. De hithörande arterna afvika betydligt från den typiska fjärilformen, kroppen ï stor och ofta tjock, vingarne jümförelsevis smala; och medan de hos fjürilarme i allmänhet äro betäckta med ett taitt och fint färgstoft, äro de hos dessa species rattenklara, blott med mulantag af rissa kanter, aidror och birder, hvilka äro fürsedda med stoftfjiall och lidlragat att frambringa teckningar; motsrarande skuggningarna pâ de imiterade steklarnes vingar. Medan deras nïrmaste slïgtingar, Sphingiderm, äro i rörelse endast vid nattens inbrott, flyga âter Setiiderna om dagen, sasom de insekter, hvilkas mask de bära.

Fran fjärilarne torde vi lämpligast öfverga till trăvingarnes ordning, Diptera. Ocksa här förekommer nämligen en, ofta anda in i de minsta detaljer giende imitation till färg, teckning, pubescens och ringarnes skuggning efter getingar oph andra steklar; ocksa här möta oss mer än en ging namm, siulana som resniformis, apiformis, bombyliformis. tydande pá denna omstiundighet. Det lider intet tvifvel att ju icke dema fiirklädnal tjenar de oberiipmade flngorna till ett utmïrkt skydd. Hufrndsakligen förekommer densimma bland Syrphidema och doras närmaste slägtingar, men är icke heller frammande för nigra andra fimiljer. 
Nyligen har den ryske dipterologen Portschinsky publicerat en, sisom det synes, symerligen intressant, men tyvärr pá ryska affattad afhandling ofver de inom Rysslands fauna förekommande humlelika flugorna ${ }^{1}$ ). Mânga af dessa trâvingar, af hvilka vi redan i det föregiende ontalat Volucella bombylans, lefra under sin larv-period i humlornas bon och delvis af deras larver och behöfva sin kostym för att kunua lista sig dit in utan att räeka nagon misstanke. Symnerligen amnärkningsvärd är den polychroism, som förekommer hos Volucella. V. bombylans uppträder nämligen i flere färgvarieteter eller mâhıända rättare raser, hvilka visa en anordning af fürgerua motsvarande den, som är utmärkande för den art humla, hos hvilken i frịga varande ras gästar. Sálunda lefrer den typiska formen hos Bombus rajellus, lapidarius, med flere, varieteten plumata hos $B$. hortorum och lucorum, varieteten hamowhoidalis hos B. syluarum, agrorum och muscorum, o. s. v. Inalles uppräknar och beskrifver ofvan anförda fürfattare icke färre än trettioen arter flugor frán europeiska Ryssland, hvilka mer eller mindre ïro förklädda efter humlor och hvilkas lefuads historia i de flesta fall står i nâgon relation till dessas ${ }^{2}$ ).

Pá samma sütt som humlor och bin i sina nästen oroas af der lefvande flugor, hysa de ïfren derstädes parasiter af den ordning, de sjelfra tillhöra. Salunda uppträda arterna af ett bislïgte, Nomada, snyltgästande hos species af deu ïfrenledes till bien hörande familjen Andrenide; och de likna antingen getingar eller Andrena-arter. Pá samma sätt äro parasithumlorna af slägtet Apathus nästan fullständigt lika de lıumlor, i lıvilkas bou de husera. Bland steklarne förekonma sâledes äf-

1) Труди Рнсск. ептом. овчест. 1876, pр. 103 ff.

2) Till Bombus muscortem lhänföra sig icke fürre än îtta bombyliforma arter, till B. hortorum och lucorum fem, till B. tcricstris, cullumanus och sylvarum tre, till B. fragrans, lapidarius, rajcllus och lapponicus tva samt till B. agrorum och apricus en. Af de till den skandinaviska faunan hörande diptera sammanstialles Laphria flave med B. muscorum och sylvarum, Cheilosia oestracca likasi, Arctophila bombiformis med B. hortorum och lucorum, Eristalis intricatus med B. muscomem, hortorum och apricus, E. apiformis med B. caucasicus, Mallota megilliformis med B. muscorum, o. s. v. 
ven, om ock mindre tahikt, maskerade arter; förklädnaden eger här rum blott efter species af samma ordning ${ }^{1}$ ). Steklar, färsedda med gadd, behöfva icke nâgon mask i orch für skydd emot fienden; här gäller det ett anmat mâl, detsamma som för Volucella, nämligen att öfverlista genom sin likhet de värdar, pî hvilkas bekostnad de skola lefva. Vi se salunda att mer än en grund kan förefimnas för maskeringen. pí samma sätt som detta i en föregînde afdelning redan blifvit pâvisadt med hänsyu till den protektiva fürglikheten; men i hvarje fall hänföra sig fenomenen dock städse till en shtorsak: uppräitthallandet och bevarandet af arten, vare sig sedan genom skydd mot fiender eller genom möjliggörandet af existensen pá annat sütt.

Tnman vi hegymma några betraktelser öfver nu anförda företeelser, mâ det vara oss tillâtet att ämmu öka raden af fakta med naggra hittills mindre observerade. Medau vi inom Lepidoptera, Diptera och Hymenoptera funnit mer eller mindre talrika exempel pii mimiska former, synas deremot saidana saknas helt och hâllet inom Nenroptern och Orthoptera, sâ vidt vâr fauna är i frâga. Detta fâr äfven sin förklaring, dâ vi betänka att särskildt af den fürra ordningen mânga arter (t. ex. Chrysopa, Here nattsländor, Phryganea.) skyddas af en obehaglig, stundom olidlig lukt, att andra sâsom dagslïndorna, Ephemeriderna, bland Pseulo-orthoptererna, behöfra lefva sîsom imagines blott nâgra timmar för att fullborda sin rol i naturen, medan ater t. ex. Libelluliderna, trollslïndorna, räddı sig genom sin snabba flygt, och de flesta äkta rätvingar, syrsor och gräshoppor, ega en högt uppdrifven färdighet att genom lânga skutt undfly sina förföljare, hvarjimte de ofta äro skyduade af protektiva färger. Icke heller kumna vi pâminna oss nigon $\mathrm{i}$ egentlig mening mimisk

1) För en ytlig betraktelse kunde äfven nâgra andra fall bland vâra hymenoptera förefalla såsom mimiska, ehuru de i sjelfra verket icke kumna hetraktas sâsom sidana, da de i frâga rarande arterna icke stâ i nigot som helst förhaillande till hvarandra. Sá paiminna myror, Pezomacher och Mutillor ganska mycket om hvarandra; men detta iir en typ, som iir karaliteristisk für familjerna Formicǖa, Pezomachida och Mutillide sisom sidana $\mathrm{i}$ deras helhet, under det ingen speciel imitation efter en eller annan bestïmd art förekommer. 
skalbagge, tillhïrande vâr fauna, ty likheten hos Clevus formicarius med en myra är i sjelfva rerket föga utprïglad och torcle bero blott pî en tillfüllighet.

Deremot förekomma flere fall af 》mimicry inom skimnbaggarnes ordning, Hemiptera, livilka äro af största intresse. Vi erimra härvid derom, att ocksâ denna ordning karakteriseras genom sugande mundelar, likasom fjärilarnes och flugornas, inom hvilka äfrenlecles tlere maskerade former upprisats, än bland de insektgrupper, hrilka i bitande käkar syuas hafva ett starkare försvarsmedel. De fall af förklädnad, som förekomma inom nordens hemipterfauna, hänfüra sig väsentligen till trâ typer. Den ena utgöres af en mask efter myror, den andra efter vissa skalhaggar. Dá jag i miu, redan i första afdelningen af denua uppsats citerade afhandling om »mimiska hemiptera" närmare redogjort för dessa, vill jag här blott i korthet anföra de märkligaste fallen. En art af Capsidernas familj, Myrmecoris gracilis, är med hänsyn till vingarne hvad man kallar polymorf, eller, med andra ord, hon förekommer under tvá olika former, eu ined fullt utvecklade och en med så godt som alls inga vingar. Denna senare form, under hvilken båda könen uppträda, är till den grad lik en myra, att mer än en person för mig förklarat sig icke kunna âtskilja hemne frân en sådan. Jag har blott två gînger funnit denna art, hvilken, likasom alla maskerade former, ïr sällsynt; den ena gângen tillsamman med röda stackmyran, den andra med Formica fusca. Men dessa exemplar visade till fürgen stora olikheter, lämpade fullkomligt efter färgen hos de begge myrarterna, i hvilkas sällskap de lefde; här förekommer sålunda en polychroism, likartad med den, som ofvan pâpekats hos Volucella; och denna omständighet synes tala för att dessa skimubaggar's myrmecoïda skapnad, om nágonsin, är en verklig förklädnad, ehuru arten af deras relationer till myrorna ännu icke kan sügas vara utredd. Det andra mera eminenta fallet af maskering efter myror förekommer hos Systellonotus triguttatus, ¿ifvenledes en capsid, hvilkens hane städse är långvingad och liknar andra arter af samma familj, hvaremot honan, sii vidt man hittills käuner, förekommer endast med helt korta vingstumpar och, om möjligt, i ännu högre grad än den nyss i frâga varande 
capsiden imiterar myror, näunligen sïrskildt den lilla, allmänna svarta myran, Lasins niger, i hrilkens boningar jag uppreparte ginger fumnit densamma ${ }^{1}$ ). Likhetron iir sî stor, att jag mer än en gâng af misstag gripit en myra i stillet för denna kortvingade capsid-hona.

Hvad âter beträftar de skimnlaggar, hvilka äro fürklädda efter vissa coleopterer, nämligen Ceratocombus muscomom samt homorna af Myrmedobia coleoptrata och Microphlysa pselaphöres, sâ efterhärma de alla skalbaggur, som lı̈ra till sidana familjer, hvilka äro symmerligen rika pâ myrmecofila species, det vill säga arter, hvilka vistas i myrormas nästen och af dem antingen tolereras eller till och med särskildt omvârdas. Sallundir imiterar Cerrotocombns vissa Comticavier eller Lathridier, Myrmedobia den lilla skalbaggen Alexia nitifera och Mricrophysa arter af familjen Pselaphide. Med undantag af den sist naimnde af dessa skimubagar, hafva de afven sjelfva blifvit fuma i siillskap med myror. Och dí man vet att deras näjmaste slägtingar, Anthocomidema, lefva af rof och i all symmerhet af bladlöss, ligger den förmodan nära till hands, att ocksil de 11 i frâga varande arterna lifnära sig af sâdana och mâhünda ega sin mask efter de af myrorma tolererade skalbaggarne, för att sálunda förklädda i fred kumna smyga sig ned till de bladlöss-hjordar, livilka myrorna, sâsom kïudt, hâlla ochr uppü̈da i sina boningar. Detta, likasom mycket amnat, som afser de mimiska arternas lefuads historia, mâste dock tills vidare betraktas blott sisom en lös hypotes, som endast visar huru mycket i dessa frigor ïnmu stîr att utforska och hrilket rikt fält till iakttagclser här gifves it enluvar, som lifligare intresserar sig för insekternas biologi. 'Iy om äfven i mânga fall maskeringen af en eller amman orsak otvifrelaktigt är bevisad, aterstar dock ej mindre ofta att utreda len verkliga beskaffenheten af de förhallanden, i hrilka de bâda arterna, den efterapade och den efterapande, stá till hvarancir.

Sâ langt hafva vi i alla häudelser kommit, att ingen alvarligare entomolog i vâra dagar mera kan tala om blott en sbe-

$\left.{ }^{1}\right)$ Med samma myra förekommer afien ej stillan en liten svart, myrlik spindel. 
symnerlig analogi , en »egen naturens lek «, till följd hvaraf vissa arter af vidt skilda ordningar blifvit skapade och fürgade till förvexling lika hrarandra. Man har kumnat upprisa ett bestämdt kausal-sammanhang dem emellan, som icke kan bortresonneras.

Men under det förklädnaden" i insektverlden förekommer muder sa manga olika former ${ }^{1}$ ), saknas den da helt och hallet bland de hïgre djuren, hos ryggrads-djuren? Detta är en fråga, som ligger nära till hands och hvilken äfven Wallace gjort sig. "Dii ri emellertid betänka«, svarar han (1. c. pag. 99), salla de vilkor, som äro nödvïindiga för att frambringa en god illusorisk likhet, skola vi snart inse att den blott sällan kan förekomma hos högre djur, emedan dessa ega ingen sâdan lätthet för frambringandet af nästan oändliga modifikationer af den yttre formen, som ligger i sjelfra insektorganismens natur. Dit det yttre skalet hos insektema in mer eller mindre fast och hornartadt, äro de förmögua af nästan en obegrüusad formvexling utan nâgon väsentlig förändring till den inre strukturen. För manga grupper äro vingarne rigtiga karakterer, och dessa organer kumna mycket modifieras bade till form och fürg, utan att derfür deras speciela funktioner behöfra uppgifvas ${ }^{2}$ ). För öfrigt är insekternas antal sil stort och förefinmes det en sâdan olikhet i former

1) Yi anse oss häir böra pâpeka :imu ett slag af förkläilnal eller maskering, eluru det visserligen nàgot ligger pa sidan af det imme, vi behandlat. Vi mena den mask, som djmen i vissa fall förfä rliga ât sig sjelfva, föl att derunder clïlja sig. Flere Chermes-larver (vextloppor) omgifva sig med en hvit ullig sekretion, larver och nymier af Cercopider eller skumcicader med ett slags spott (pgror-spott", sorm-spotts); larverna af Psycheoch andra fjüril-arter lefva i smá sïckar, som ofta likna små pinnar o. d., der de stai fistade vid blad, plank, qristar, meal mera. Enlwar kitimer att larverna till natıslindorna (Phryganeiderna) fürfärdiga särdeles lionstrika rär, i hrilka de lablla sig lolda, och hvilka mästerligt erinra om afbrutna stjelkar, med mera. Och slutligen kan atven hvarje pup-hylsa betraktas sassom en slags mask. Fürklaringeu öfrer uppkomsten af sådana slags förkliidnader kan iffen staillas $\mathrm{i}$ samband med den, som vi nedan, enligt Wallace, skola lemna äfer "mimicrya. I det stora hela hafva troligen iifven här samma grundorsaker varit rerlisamma.

2) I vissa fall, saisom hos Myrmecoris sant honorma af Systellonotus, Myrmedolia och Microphysa, fürïnlras dock vingarne inula derhän, att de alls icke kumma brukis.

O. I. R. 
och proportioner inom hvarje grupp, att utsigterna för ett tillfülligt nürmande i yttre skapnad, form och färg emellan tví insekter af olika grupper äro mycket stora; och det är dessa slumpvisa tillnärmelser, hvilka utgöra basen för förklädnaden och hvilka fortsättuingsvis fullkomnas genom de varieteters afvel, som gå i en fördelaktig rigtning med hänsyu till rariationen.

》Deremot ï skelettet hos de vertebrerade djuren ett inre, och deras yttre form beror nästan uteslutande pá dess proportioner och utseende, hvilka ater ïro noggrant afpassade efter de funktioner, som äro nödrändiga för djurets välbefinnaude. Formen kan derför icke hastigt modifieras genom variation och den tumna och bojliga huden tilliter icke uppliomsten af sadana utskott, som si̊ ofta förekomma los insekterna. Autalet arter inom hvarje grupp och i samma land är äfven jämförelsevis ringa, och sålunda förminskas betydligt utsigterna för den första tillfälliga likheten, hvilken är nödväindig för att det naturliga urvalet skall kumna verka. Vi hafva svârt att tänka oss möjligheten af en förklädnad, hvarigenom elgen skulle kumna undslippa vargen eller buffeln tigeru

Emellertid framhaller WVallace ibland kräldjuren några fall af verklig "mimicry", dâ oskadliga ormar i tropikerna imitera giftiga sådana, men härvid bör man erimra sig ormarues skapnad och att redan blott och bart eu fürgimitation lät leder till mâlet inom en klass, som visar $i$ det hela taget sâ ringa mångfald af former. Ocksi bland fäglar och däggdjur ommämnas nígra exempel, hvilka syuas närma sig till förklädnad; ett sâdant eger äfren vâr fauna $\mathrm{i}$ göken, lvilken har sin färglikhet med höken att tacka för den gamla sägen, som ämnu går igen bland allmogen i vâra bygder, att hau nämligen seuare pâ sommaren förändras till denna roffagel.

Dí vi nu fullföljt uppräknandet af de mera anmärkningsvärda fall af maskering, vi känna frân vâr fauna, vilja vi vända oss till de förklaringar, hvilka blifvit gifua öfrer det fenomen, för hvilket vi redogjort. Tre eller (med den af Wallace accepterade och närmare utförda, om äfven först af den suillrike »naturforskaren pa Amazonfloden«, mr Bates frumstälda) fyra olika sätt att tolka detsamma hatváa af' naturforskarene blifvit försökta. 
Professor WVestwood erkümner visserligen tillvaran af mimicry", äfrensom dess samnolika nytta för insekten, men han anser att hvarje art blifvit skapad sålunda förklädd för att derigenom skyddas.

Mr Murray är i sitt arbete 》Disguises of Nature« böjd för den åsigt, att likhet i föda eller lefnadssätt på en eller annan okïnd väg möjligen skulle ha framkallat likhet $\mathrm{i}$ utseende.

Då frâgan diskuterades i Entomological Society of London, framstäldes ytterligare af nur Sharp den förmodan, att ärftlighet eller àtervändande till tidigare stamtypers form och färgdrägt kunde hafva frambragt mannga af dessa maskeringar.

Emot antagandet af en särskild skapelse af mimiska arter' framställa sig en mängd högst väsentliga inkast. Det svåraste ¿ir att det förefinnes en allt för tydlig gradation i dessa företeelser, ända frin en blott protektir färglikhet till den mest noggrant genomförda maskering, ett faktum, som osökt leder vâr tanke på en naturprocess såsom orsak till fenomenet. En annan, icke mindre vigtig invändning är den, att »mimicry« är af nytta för och förekommer blott hos sådana arter och grupper, hvilka äro sällsynta; antoge man teorin om en särskild skapelse, så skulle alltså de imiterade arterna hafva blifvit skapade rika på individer, de imiterande âter fattiga på sidana. Vidare skulle det hafva varit nödvändigt att dessa båda arter under alla dem mötande lefnadsförhållanden, hvilka för öfrigt i naturen så ofta sträfva till att utjämma och förändra proportionerna emellan individernas antal, likväl särskildt och framför andra arter under loppet af sekler hade blifvit af en magt utom dem bibehâllna $i$ deras respektiva talförhållanden; men $\mathrm{i}$ sådant fall har hela ändamålet med deras säregna protektiva karakterer förfelats. Ännu en tredje svårighet vid antagandet af en särskild skapelse-akt för hvarje art imneligger $\mathrm{i}$ den tanken, som ovilkorligen tränger sig på en, att det nämligen för skaparen synes vara något alldeles onaturligt att dana sådana mimiska arter, då han lika väl hade kunnat direkt gifva dem något bättre försvar i den blifvande kampen för tillvaran, utan att förse dem med ett sådant, så att säga »i cirlkel giende«, skydd.

De båda andra förklaringarna, hvilka i korthet má kallas 
teorierna om likhet i vilkor och om ärftlighet, öfverensstämma båda deri, att de göra förklädnaden till en biomständighet, som icke står i något nödvändigt samband med de maskerade arternas välfärd. Men ett sådant har emellertid blifvit ovederläggligt bevisadt $i$ en stor mängd fall.

Vi må vidare erinra oss att förklädnaden är inskränkt blott till rissa grupper, men förekommer deremot alldeles icke inom andra, ehuru de lefva under samma förhâllanden; hvaremot just denna likhet $\mathrm{i}$ lefnadssiitt $\mathrm{m}$. $\mathrm{m}$. borde mer eller mindre verka på alla former $i$ en viss trakt, under det àter â andra sidan arflikheten i samma grad borde inverka pâ alla med hvarandra beslägtade species. Det allra vigtigaste skälet emot dessa teorier lemnas emellertid af de fall, da det ena könet, nästan alltid hanen, är typiskt bildad, hvaremot det andra afviker frân den ranliga skapnaden hos den familj, till hvilken arten hörer, och är danadt helt och hallet efter en modell, ofta hemtad frân en till och med fullkomligt annan ordning. Om någonsin, borde väl samma lefnadsrilkor verka lika pâ olika kön af en och samma art, eller arflikheten och atervändandet, sbakslaget «, till tidigare stamtypers form och färgdrägt uppträda hos det ena sâ väl som hos det andra.

Icke heller lemna de ofvan anförda teorierna någon förklaring på det faktum, att de härmande arterna $\mathrm{i}$ allmänhet äro sällsynta, de efterapade rika pa individer, lika litet som derpa, att det företrädesvis äro vissa, på ett eller annat sätt skyddade grupper, som blifva imiterade, sîsom t. ex. inom vâr fauna bin, humlor, getingar och myror, bland exotiska skalbaggar hufvudsakligen Malacodermer och Hispider, hvilka utmärkas af en obehaglig sekretion.

Huru vill teorin om arflikheten förklara att de imiterande och de imiterade arterna städse bebo samma trakt, under det deras närmaste slägtingar deremot stå att finna på ofta lângt aflägsna delar af jordklotet? Och icke heller kan densamma, lika litet som teorin om de liknande lefnadsvilkoren, uppställa någon grund hvarför denna likhet emellan tvi̊ arter af olika grupper blifvit blott en ytlig sådan, en "förklädnad«, icke en verklig likhet. Och vidare kan man enligt dessa hypoteser pá in- 
tet vis förklara alla dessa egendomliga imitationer efter bark, blad, mossa, pimnar, exkrementer, on hvilka vi i första afdelningen af vâr uppsats talat! Och slutligen anknyter sig till alla dessa invändningar det gradrisa $i$ hela denna följd af företeelser, hvilket vi redan i det föregâende mera än en gâng framhâllit.

Den enda utläggning af dessa fenomen, som mera än de andra tillfredsställer oss, âterstâr i Wallaces eller, om man så vill kalla den, Bates' teori. Vi hafva redan delvis gjort bekantskap med densamma vid frâgan om den protektiva färgimitationen cch likheten mellan insekter och vissa vextdelar m. $\mathrm{m}$. Vi skola ännu en gâng âtergâ till denna teori om »bevarandet af det ändamâlsenligaste« och vi lâta mr Wallace sjelf tala: »I naturen finnes en allmän öfverensstämmelse«, säger han (1. c. pag. 123), „emellan ett djurs färger och dess vistelseorts. Arktiska djur äro hvita, ölendjur sandfärgade, de som bo mellan löf och gräs gröna, nattljur mörka. Detta är visserligen icke en universalregel, men en mycket allmän och blott sällan omvänd sats. Gâ vi nâgot vidare, sâ finna vi fâglar, kräldjur och insekter sá fürgade och tecknade, att de likna fullkomligt klippor, bark, löf, blommor, pâ hrilka de pläga sitta, och - derigenom äro de pâ ett verksamt sätt dolda. Ännu ett steg framåt, och vi hafva insekter, hvilka sâ väl till form och färg exakt likna bestämda blad, pinnar, mossberuxna qvistar eller blommor, och i dessa fall understöda egendomliga vanor och instinkter bedrägeriet och dölja ytterligare djuret. Vi komma nu till en ny sida af fenomenet, och komma sâ till varelser, hvilkas färger hvarken dölja dem, ej heller göra dem lika föremål ur vexteller sten-riket, tvärtom äro i ögonen fallande; men de likna då fullkomligt någon annan varelse af en alldeles skild grupp, under det de i sitt yttre utseende mycket afvika frân dem, med hvilka de till följd af alla väsentliga delar af sin organisation äro närmast beslägtade. De uppträda nästan såsom skådespelare eller maskerade personer, som mâlat och klädt ut sig på skämt, eller såsom bedragare, hvilka vilja passera som väl kända och aktningsvärda medlemmar af samhället. Hvad är meningen med denna främmande förklädnad? Nedläter naturen sig till bedrä- 
geri och maskerader? Vi svara: det gör hon icke. Hemes grundsatser äro dertill för alvarsamma. Det fimes ett ändamâl, en nytta i hvarje detalj af hennes rerk. Likheten af ett djur med ett annat är till sitt vïsende af samma natur, som likheten med löf eller bark eller öknens sand och motsvarar fullkomligt samma ändamâl. I ett fall vill fienden icke angripa löf eller bark, och sâlunda är bedrägeriet ett skydd; i andra fall anfalles det efterhärmade djuret af âtskilliga orsaker icke af fiender, som annars vore nära till hands för den ordning, till hvilken den härmande arten hör, och pá detta sätt erhâller denna senare ett synnerligt verksamt skydd. $\mathrm{Vi}$ hafva med afsigt visat att förkläidnaden $i$ bâda fallen är af samma natur genom att frân samma grupper framhilla arter, hvilka likna vexter, och andra, som imitera lefvande djur af frimmande grupper. - - - En fortsatt undersökning afslöjar för oss det faktum, att i atskilliga fall af dessa båda slag af maskeriug houan ensam är förliadd ${ }^{1}$ ); veh dâ det kan bevisas att honan hehöfver skydd vida mer an hanen, och att hennes bibehallando vid lif under en mycket längre tid är fullkomligt nökväindigt för racens fortbestand ${ }^{2}$ ), hafva vi

${ }^{1}$ ) Af de stickande steklarne ïro bîda könen lika grant färgade, likasa af Carabider, Coccinellider, Chrysomelider, Cetoniider, Buprestider, med flere skalbaggar, som hafva i hârdhet, lukt, smak och dylikt ett sürskild skydd; men bland de arter, hvilka utmärlia sig för protektiv färglikhet, är det ofta nog just honan, som företräidesvis eller uteslutande har matta, döljande färger, och ibland de maskerade formema hafva vi framhallit hur'usom endast detta kön iir mimiskt af Diaphora mendica, Systellonotus, Myrme. lobia och Michrophysa.

O. M. R.

2) „Künens inbördes betydelse varierar mycket inom olika djurklasser. Bland de högre ryggradsdjuren, hos hvilka antalet af i hvarje kulle födda ungar är ringa och samma individer yngla flere âr a lad, är bâda könens hevarande nästan lika vigtigt. I alla de talrika fall, i hvilka hanen skyddar honan och hennes afkomma eller hjelper till att förskaffa dem föda, ükas hans betydelse i naturens ekonomi, ehuru den måhïnda aldrig iir lika stor som honans. Hos insekterna eger ett helt amnat fall rum. De para sig blott en enda gůng $\mathrm{i}$ lifvet och hanens förlïngda tillvara iir i de flesta fall fullkomligt onödig för rasens bestând. Honan deremot måste ännu lïnge fortlefva för att lägga sina ägg pă en plats, lämplig för affödans utveckling och förkofran. Deraf den stora olikheten i behof af skydd für de bâda könen. Och vi böra derför vünta oss att den för honan egna protektionen hos ha- 
deri yttermera ett vitnesbörd för att likheten i samtliga fall tjenar samma stora indamal - artens bevarande«.

》Da vi försökte förklara dessa företeelser sâsom âstadkomna genom »föränderligheteu " och det »naturliga urvalet«, utgingo vi fran det faktum, att hvita afarter myeket ofta synas fortbestá och förökas, när de skyddas för fiender ${ }^{1}$ ). Vidare veta vi att varieteter tillfälligtris uppstî, visande mânga andra fürger; och dâ de raser, hvilkas färger äro för dem skadliga, sâ att de lätt röja dem, utrotas, hvaremot de, hvilka i färgen ega ett skydd, ovilkorligen lättast bibehâlla sig, sâ behöfves intet vidare för att förklara polar- och öken-djurens skyddande färger. Men om vi en gîng gî in härpa, sâ fimnes det en sâdan sammanhängande och gradvis framträdande serie af exempel pâ hvarje slags skyddande likhet ända till de mest underbara fallen af hrad vi benämnt »mimicry", att vi icke förmå uppdraga nâgon gräns och säga: sâ lângt kan föränderligheten och det naturliga urvalet förklara företeelserna, men för alla de öfriga fordras en mägtigare orsak .

Medan sâlunda alla de andra framhâllna hypoteserna antingen erbjuda en mängd svirigheter eller till och med direkt stá $i$ strid med nâgra bland de mest konstanta och anmärkningsvärda fakta, för livilka vi ofvan redogjort, synes deremot IVallaces teori om »bevarandet af det ändamâlsenligaste eller med andra ord den sâ kallade »utilitets-principen « vara den enda, till lıvilken de särskilda fallen låta hänföra sig och ur hvilken de kumna förklaras.

Och häri, likasom i sâ mînga andra af den nyare naturalhistoriens resultat, röjer sig skönjbart den befruktande inverkan

nen vore mindre utbildad eller alldeles saknades. I sjelfva verket hestyrka fakta fullkomligt denna suppositions. Wallace, pp. 111, 112.

1) Här torde vara plats att omnämna det Here fjärilar, hvilka annars förekomma i ljusare färger, uppträda i Britannien och särskildt i dess stenkols distrikt med mörka, nüstan svarta varieteter, en företeelse, som man försökt förklara på mánga sütt, men hvilken d:r Buchanan White i sthe Entomol. Monthly Magazines (1877) vill hänföra till en adaption efter den allmänna färgtonen hos marken $\mathrm{i}$ ofvan nämnda omriden, sâsom vi tro icke utan skäl.

O. M. R. 
af Darwins arbeten. Läsaren har redan af denna uppsats fatt en inblick i hvad man fürstâr med sdet naturliga urvalet, hvars framhâllande just utgör hufvudmomentet i Darwins selektionsteori, förutan hvilken äfven de af oss demna gîng behandlade företeelserna ännu länge hade fatt vänta pâ en vetenskaplig förklaring.

Väl sant att vi änuu i många fall stá blott mer eller mindre dunkelt anande inför mägtiga, evigt verkande lagar, hvilkas spâr och tillämpning vi se, men hvilkas verkliga art blifvit oss fördold. Men vi stâ dock inför lagar, och veta att »allt, sâ väl det höga som det lâga, ür underkastadt deras herravälde ${ }^{1}$ ) samt att intet är ett verk af slumpen. Och deri ligger just naturvetenskapens menniskoanden höjande inverkan, att hon visar oss dessa stora, mägtiga lagar verksamma inda in $\mathrm{i}$ de ringaste småsaker. Äro dess sanningar äfven ofta textade med den minsta tänkbara petit-styl, sâ innehâlla de dock alltid stora tankar, tankar, framför hvilka vi stamna i beundray, och hvilka, dá vi förmâtt läsa dem, uppfylla oss med en egen lycksalig kämsla, svâr att förklara och uttrycka, - en känsla likasom af ett örnsesidigt gifvande och emottagande, ett utbyte af idéer emellan naturen och menniskoanden. Hvad den senare anar, det bekräftar den förra, och hrad denna sàsom ett frö gömmer inom sig, det uppspirar i ljuset af den menskliga tanken till en skön planta med ständigt nya grenar, blad och blommor. Detta är menniskoandens umgänge med Gud i naturen.

1) $>\mathrm{Om}$ förkläłlnad $\mathrm{i} \nu \mathrm{U}^{*}$ rår tids forskning», 7, p. 63. Ehuru Wallaces arbete i denna förtjenstfulla serie af populärt vetenskapliga uppsatser redan hlifvit gjordt till föremil för ett referat, hafva vi dock icke trekat at upptaga frågan särskililt für finska läsare, så mycket mer som vîr bearbetning af densamma delvis ä gjord ur vissa afvikande synpunkter. 





